\title{
THE JOURNAL OF PHYSICAL
}

Subscriber access provided by Caltech Library

Article

\section{Tunable Chiral Second-Order Nonlinear Optical Chromophores Based on Helquat Dications}

Laura E R Buckley, Benjamin John Coe, Daniela Rusanova, Vishwas D Joshi, Sergio Sanchez, Michael Jirásek, Jan Vavra, Dushant Khobragade, Lukas Severa, Ivana Cisarova, David

Saman, Radek Pohl, Koen Clays, Griet Depotter, Bruce S. Brunschwig, and Filip Teply

J. Phys. Chem. A, Just Accepted Manuscript • DOI: 10.1021/acs.jpca.7b06057 • Publication Date (Web): 13 Jul 2017

Downloaded from http://pubs.acs.org on July 14, 2017

\section{Just Accepted}

"Just Accepted" manuscripts have been peer-reviewed and accepted for publication. They are posted online prior to technical editing, formatting for publication and author proofing. The American Chemical Society provides "Just Accepted" as a free service to the research community to expedite the dissemination of scientific material as soon as possible after acceptance. "Just Accepted" manuscripts appear in full in PDF format accompanied by an HTML abstract. "Just Accepted" manuscripts have been fully peer reviewed, but should not be considered the official version of record. They are accessible to all readers and citable by the Digital Object Identifier (DOIB). "Just Accepted" is an optional service offered to authors. Therefore, the "Just Accepted" Web site may not include all articles that will be published in the journal. After a manuscript is technically edited and formatted, it will be removed from the "Just Accepted" Web site and published as an ASAP article. Note that technical editing may introduce minor changes to the manuscript text and/or graphics which could affect content, and all legal disclaimers and ethical guidelines that apply to the journal pertain. ACS cannot be held responsible for errors or consequences arising from the use of information contained in these "Just Accepted" manuscripts. 


\section{Tunable Chiral Second-Order Nonlinear Optical Chromophores Based on Helquat Dications}

Laura E. R. Buckley, ${ }^{\dagger}$ Benjamin J. Coe, ${ }^{* \dagger}$ Daniela Rusanova, ${ }^{\dagger}$ Vishwas D. Joshi, ${ }^{\dagger}$ Sergio Sánchez, ${ }^{\dagger}$ Michael Jirásek, ${ }^{\ddagger}$ Jan Vávra, ${ }^{\dagger}$ Dushant Khobragade, ${ }^{\dagger}$ Lukáš Severa ${ }^{\ddagger}$ Ivana Císařová, ${ }^{\S}$ David Šaman, ${ }^{\ddagger}$ Radek Pohl, ${ }^{\ddagger}$ Koen Clays, $"$ Griet Depotter, " Bruce S. Brunschwig, ${ }^{\perp}$ and Filip Teplý*,*

${ }^{\dagger}$ School of Chemistry, University of Manchester, Oxford Road, Manchester M13 9PL, U.K.

* Institute of Organic Chemistry and Biochemistry, Czech Academy of Sciences, Flemingovo n. 2, 16610 Prague 6, Czech Republic

$\S$ Department of Inorganic Chemistry, Charles University, Hlavova 2030/8, 12843 Prague 2, Czech Republic

" Department of Chemistry, University of Leuven, Celestijnenlaan 200 D, B-3001, Belgium

${ }^{\perp}$ Molecular Materials Research Center, Beckman Institute, MC 139-74, California Institute of Technology, 1200 East California Boulevard, Pasadena, California 91125, United States 


\begin{abstract}
Fourteen new dipolar cations have been synthesized, containing methoxy or tertiary amino electron donor groups attached to helquat $(\mathrm{Hq})$ acceptors. These $\mathrm{Hq}$ derivatives have been characterized as their $\mathrm{TfO}^{-}$salts by using various techniques including NMR and electronic absorption spectroscopies. UV-vis spectra show intense, relatively low energy absorptions with $\lambda_{\max } \approx 400-600 \mathrm{~nm}$, attributable to intramolecular charge-transfer (ICT) excitations. Single-crystal X-ray structures have been solved for two of the chromophores, one as its $\mathrm{PF}_{6}^{-}$salt, revealing centrosymmetric packing arrangements (space groups $\mathrm{Pbca}$ and $P \overline{1})$. Molecular quadratic nonlinear optical (NLO) responses have been determined directly by using hyper-Rayleigh scattering (HRS) with a $800 \mathrm{~nm}$ laser, and indirectly via Stark (electroabsorption) spectroscopy for the low energy absorption bands. The obtained static first hyperpolarizabilities $\beta_{0}$ range from moderate to large; $9-140 \times 10^{-30}$ esu from HRS in MeCN and $44-580 \times 10^{-30}$ esu from the Stark data in PrCN. The magnitude of $\beta_{0}$ increases either on extending the $\pi$-conjugation length or replacing a methoxy with a tertiary amino electron donor substituent. Density functional theory (DFT) and time-dependent DFT calculations on selected tertiary amino chromophores confirm that the low energy absorptions have ICT character. Relatively good agreement between the simulated and experimental UV-vis absorption spectra is achieved by using the CAM-B3LYP functional with the 6-311G(d) basis set. The $\beta_{\text {tot }}$ values predicted by using DFT at the same level of theory are large (472-1443 $\times$ $10^{-30}$ esu in $\left.\mathrm{MeCN}\right)$. Both the theoretical and experimental results show that para-conjugation between $\mathrm{Hq}$ and electron donor fragments is optimal, and enlarging the $\mathrm{Hq}$ unit is inconsequential with respect to the molecular quadratic NLO response.
\end{abstract}




\section{INTRODUCTION}

Organic dyes are interesting from a fundamental scientific perspective, and also for various applications in advanced technologies. ${ }^{1-4}$ Besides so-called linear optical behavior involving the absorption and emission of light, nonlinear optical (NLO) effects are useful in diverse contexts. $^{5-8}$ These include well-established roles like harmonic generators and electrooptic switches, currently reliant on inorganic materials, and also newer applications such as cellular imaging and multiphoton lithography. Following many years of basic research, a notable development regarding organic materials was the commercialization of the salt $(E)-4^{\prime}-$ (dimethylamino)- $N$-methyl-4-stilbazolium tosylate (DAST). ${ }^{9-14}$ Crystals of DAST can be used to generate terahertz (THz) frequencies by nonlinear mixing of two laser beams. THz radiation has many uses, e.g. in security scanning, biomedical analysis and space communications. $^{15-19}$

NLO effects in molecules derive from hyperpolarizabilities, which relate to the response of mobile electronic charges to the oscillating electric field of a laser beam. The first hyperpolarizability $\beta$ leads to second-order (quadratic) effects, and large $\beta$ values are characteristic of acentric, $\pi$-conjugated structures with electron donating and accepting substituents. Such molecules are dye-like and absorb visible light strongly. The active cation in DAST contains an electron-accepting pyridinium ring, and related species with 2,2'bipyridinium (diquat) acceptors show even larger nonresonant $\beta$ responses $\left(\beta_{0}\right){ }^{20-23}$ For bulk quadratic NLO effects to be observed, it is usually necessary for the active chromophores to adopt a polar ordering. In a centrosymmetric arrangement, the individual $\beta$ responses cancel each other, leading to a zero bulk susceptibility $\chi^{(2)}$. Creating new molecules with high activities is relatively straightforward, but achieving suitable macroscopic structures poses significant challenges.

Chirality is an important theme in nonlinear optics. ${ }^{24}$ Removing mirror planes slightly relaxes the symmetry requirements for quadratic effects, so having a polar molecular alignment in a material is no longer strictly necessary. Any organized bulk structure, polar or apolar, composed of chiral units can in principle show quadratic behavior. Therefore, chiral 
compounds offer a major advantage in the quest for active materials. However, most relevant studies involve neutral molecules, and work with organic salts is very scarce. ${ }^{25-27}$ We have described the marked chiroptical properties of helquat (Hq) dyes, ${ }^{28}$ and subsequently NLO investigations with $\mathrm{Hq}$ derivatives containing tertiary amino ${ }^{29}$ or ferrocenyl ${ }^{30}$ electron donors. The $\mathrm{Hq}$ motif can be viewed as a hybrid of the diquat and helicene structures, and the combination of helical chirality with dye-like behavior is highly attractive for NLO purposes. Here, we describe a large series of novel Hqs functionalized with methoxy or tertiary amino electron donor groups, as an expansion of our initial studies. Full characterization by experimental methods, accompanied by theoretical calculations shows that the linear and nonlinear optical properties of these chromophores are widely tunable. 


\section{RESULTS AND DISCUSSION}
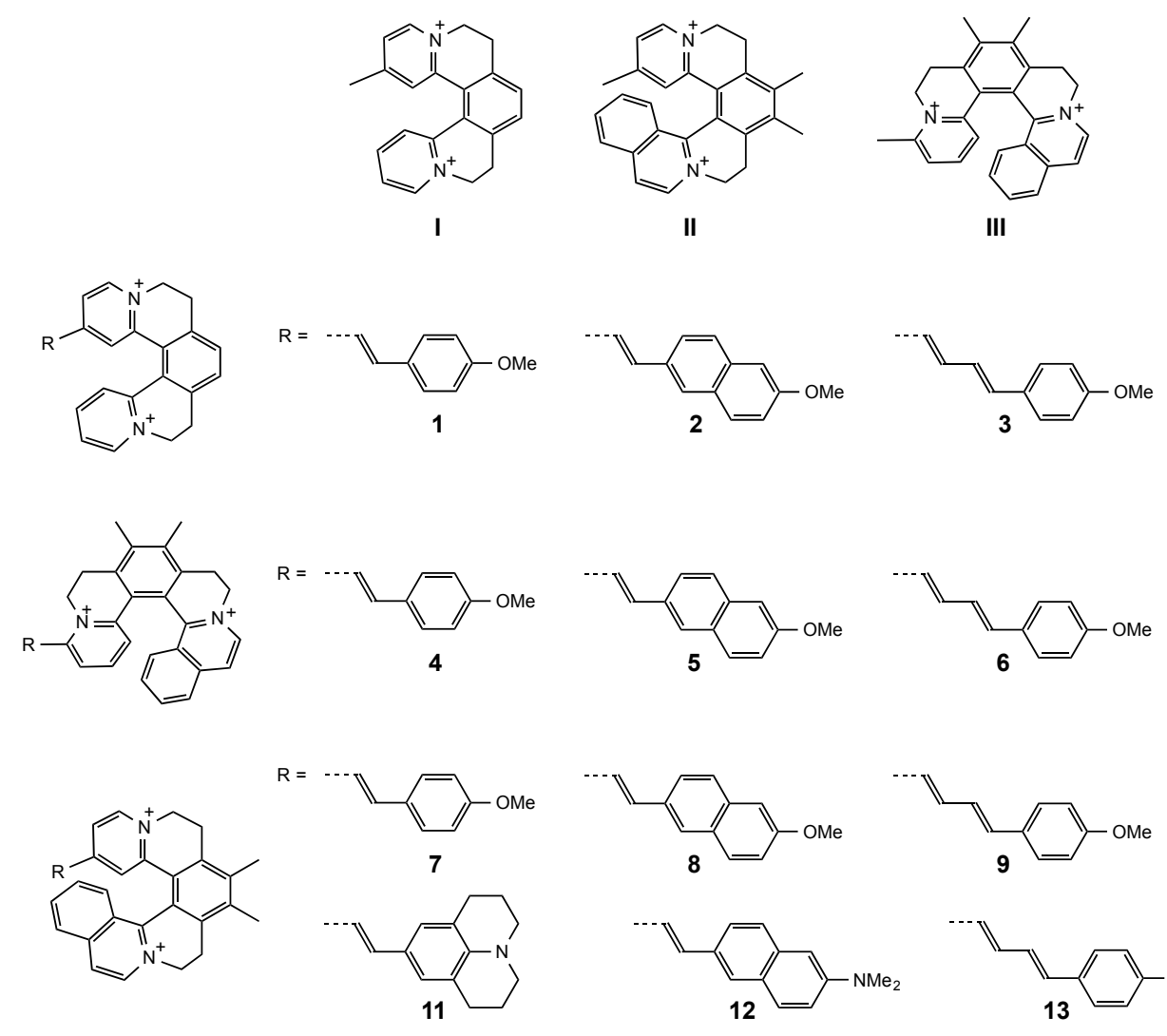

Figure 1. Chemical structures of the methyl-substituted Hq precursors I-III and the new chromophores 1-14.

Synthesis and Characterization. The new chromophores 1-14 (Figure 1) were prepared via Knoevenagel condensations between the appropriate benzaldehyde derivative and the bis-triflate salts of the methyl-substituted Hq precursors I-III (Figure 1) $28,29,31$ in $\mathrm{MeOH}$ at room temperature with pyrrolidine as catalyst. They were all isolated as their bistriflate salts and characterized by ${ }^{1} \mathrm{H} /{ }^{13} \mathrm{C}$ NMR spectroscopy (see the Supporting Information, Figures S1-S14), elemental analyses and +electrospray mass spectrometry.

The salts $[2]\left[\mathrm{PF}_{6}\right]_{2} \cdot \mathrm{MeCN}$ and $[6][\mathrm{TfO}]_{2}$ were characterized structurally by singlecrystal X-ray diffraction, and views of these compounds are shown in Figure 2. Crystallographic details are given in the Supporting Information (Table S1). 
(a)
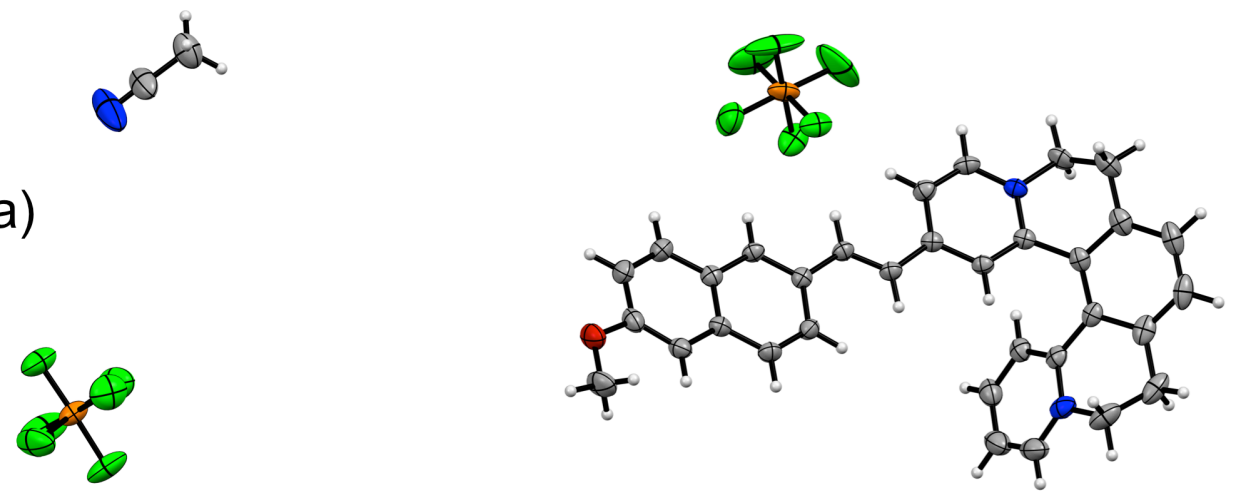

(b)

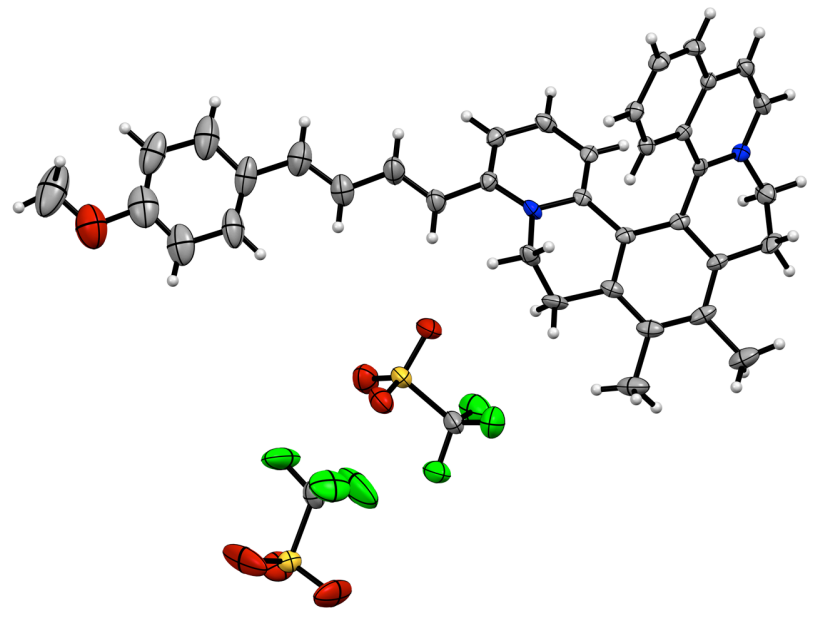

Figure 2. Representation of the molecular structures of the salts $[2]\left[\mathrm{PF}_{6}\right]_{2} \cdot \mathrm{MeCN}$ (a) and $[6][\mathrm{TfO}]_{2}$ (b), with the disorder in the $\mathrm{MeCN}$ and $\mathrm{PF}_{6}{ }^{-}$anions removed (50\% probability ellipsoids). $\mathrm{H}=$ white; $\mathrm{C}=$ grey; $\mathrm{N}=$ blue; $\mathrm{P}=$ orange; $\mathrm{F}=$ green; $\mathrm{O}=$ red; $\mathrm{S}=$ gold.

Both structures reveal the expected $E$-configuration of the vinyl units, consistent with ${ }^{1} \mathrm{H}$ NMR spectroscopy $(J=16.0 \mathrm{~Hz})$. The dihedral angle between the two pyridinium rings of the $\mathrm{Hq}$ fragment is ca. $61.1^{\circ}$ in $[2]\left[\mathrm{PF}_{6}\right]_{2} \cdot \mathrm{MeCN}$, and ca. $66.3^{\circ}$ in $[6][\mathrm{TfO}]_{2}$. The stilbazolium unit within $[2]\left[\mathrm{PF}_{6}\right]_{2} \cdot \mathrm{MeCN}$ is relatively planar, with a dihedral angle between the (naphthyl) phenyl and adjacent pyridinium rings of ca. $6.6^{\circ}$. In contrast, the chromophore in $[6][\mathrm{TfO}]_{2}$ is more twisted, with a dihedral angle between the terminal phenyl and connected pyridinium ring of ca. $25.8^{\circ}$. These compounds were crystallized from racemates and their crystals contain both enantiomers. The adoption of centrosymmetric space groups ( $\mathrm{Pbca}$ for $[2]\left[\mathrm{PF}_{6}\right]_{2} \cdot \mathrm{MeCN}$ and $P \overline{1}$ for $[6]\left[\mathrm{TfO}_{2}\right)$ means that these particular materials are not expected to show significant bulk quadratic NLO effects. 

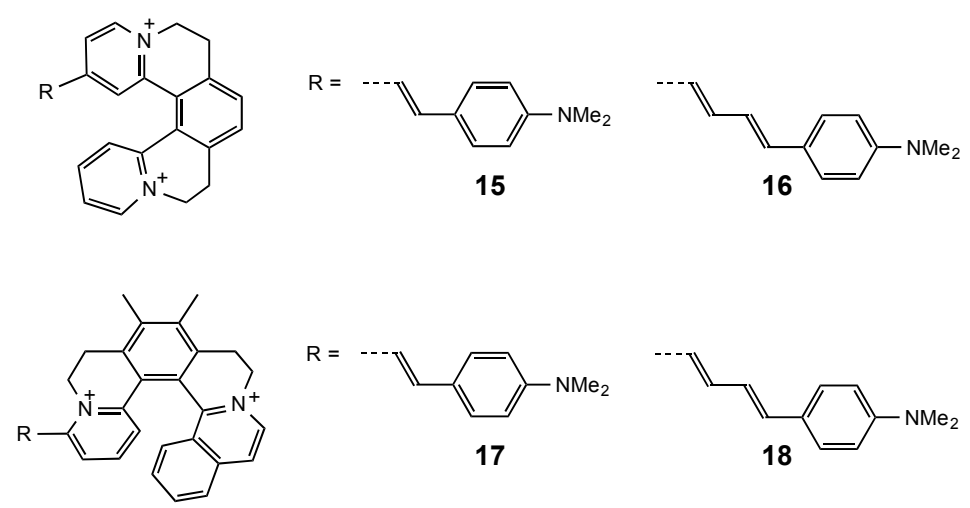

17

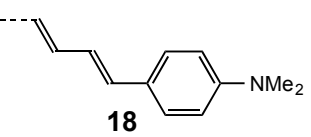

Figure 3. Chemical structures of the previously reported Hqs 15-18. ${ }^{29}$

In all cases, further intense absorptions are observed in the region $350-400 \mathrm{~nm}$, showing little sensitivity to variations in the molecular structure. For the methoxy [6]Hq species $[4-6][\mathrm{TfO}]_{2}$ (Figure 4), these additional bands overlap strongly with the lower energy absorption, meaning that the $\lambda_{\max }$ values quoted in Table 1 are only approximate. The visible 
bands for the methoxy derivatives are always blue-shifted when compared with those of their dimethylamino analogues (Figure 4). This trend is attributable to the stronger $\pi$-electron donor strength of the amino group. The shifts in $E_{\max }$ are ca. $0.6 \mathrm{eV}$ for the chromophores with a vinyl bridge $(\mathbf{1 5} \rightarrow \mathbf{1} ; \mathbf{1 7} \rightarrow \mathbf{4} ; \mathbf{1 0} \rightarrow 7)$ and ca. $0.4-0.5 \mathrm{eV}$ when a butadienyl linkage is present $(\mathbf{1 6} \rightarrow \mathbf{3} ; \mathbf{1 8} \rightarrow \mathbf{6} ; \mathbf{1 3} \rightarrow \mathbf{9})$, showing that the effect of the donor is more significant in a shorter conjugated system. Within the three series of methoxy derivatives, the visible band shows a consistent red-shifting trend, i.e. the ordering of $E_{\max }$ is $\mathbf{1}>\mathbf{2}>\mathbf{3} ; \mathbf{4}>\mathbf{5}>\mathbf{6}$ (Figure 4); $7>\mathbf{8}>\mathbf{9}$. Interestingly, the relative behavior of the naphthyl derivatives is different for the amino Hqs, and the ordering of $E_{\max }$ is $\mathbf{1 2}>\mathbf{1 0}>\mathbf{1 3}$; the same pattern is shown by the chromophores 15-18 and their naphthyl counterparts we have reported previously. ${ }^{29}$ The red-shifts of the visible band caused by adding a second vinyl linkage within the pairs $[\mathbf{1 0} / \mathbf{1 3}][\mathrm{TfO}]_{2}$ and $[\mathbf{1 7} / \mathbf{1 8}][\mathrm{TfO}]_{2}$ (Figure 5) are similar at ca. $0.1 \mathrm{eV}$.

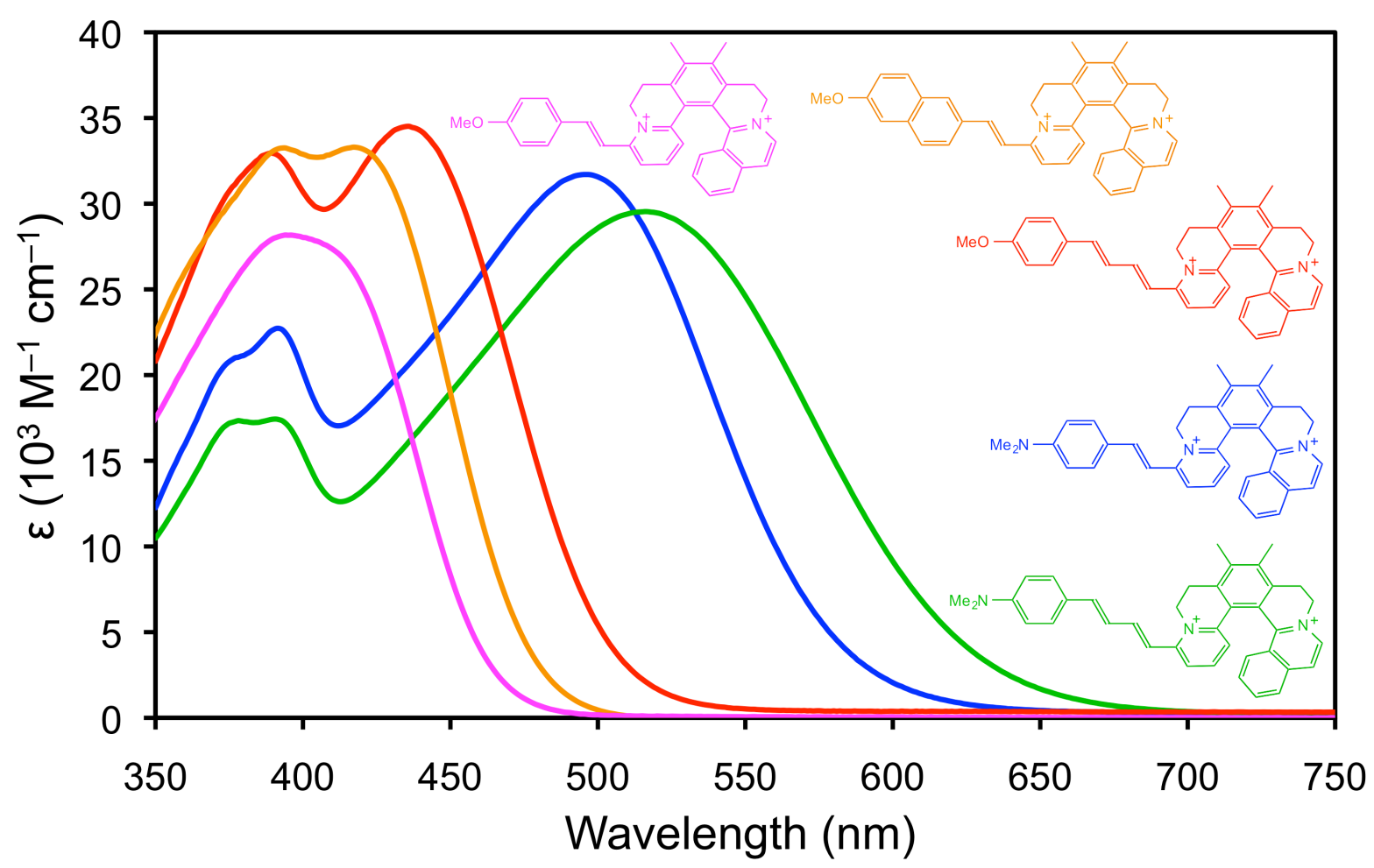

Figure 4. UV-vis absorption spectra of the $[6] \mathrm{Hq}$ salts $[4][\mathrm{TfO}]_{2}$ (magenta), [5][TfO $]_{2}$ (gold), $[\mathbf{6}][\mathrm{TfO}]_{2}$ (red), $[\mathbf{1 7}][\mathrm{TfO}]_{2}$ (blue) and $[\mathbf{1 8}][\mathrm{TfO}]_{2}$ (green) in $\mathrm{MeCN}$ at $293 \mathrm{~K}$; note the redshifts of the visible band on replacing $-\mathrm{OMe}$ with $-\mathrm{NMe}_{2}$ on moving from 4 to $\mathbf{1 7}$ or from 6 to 18 . 


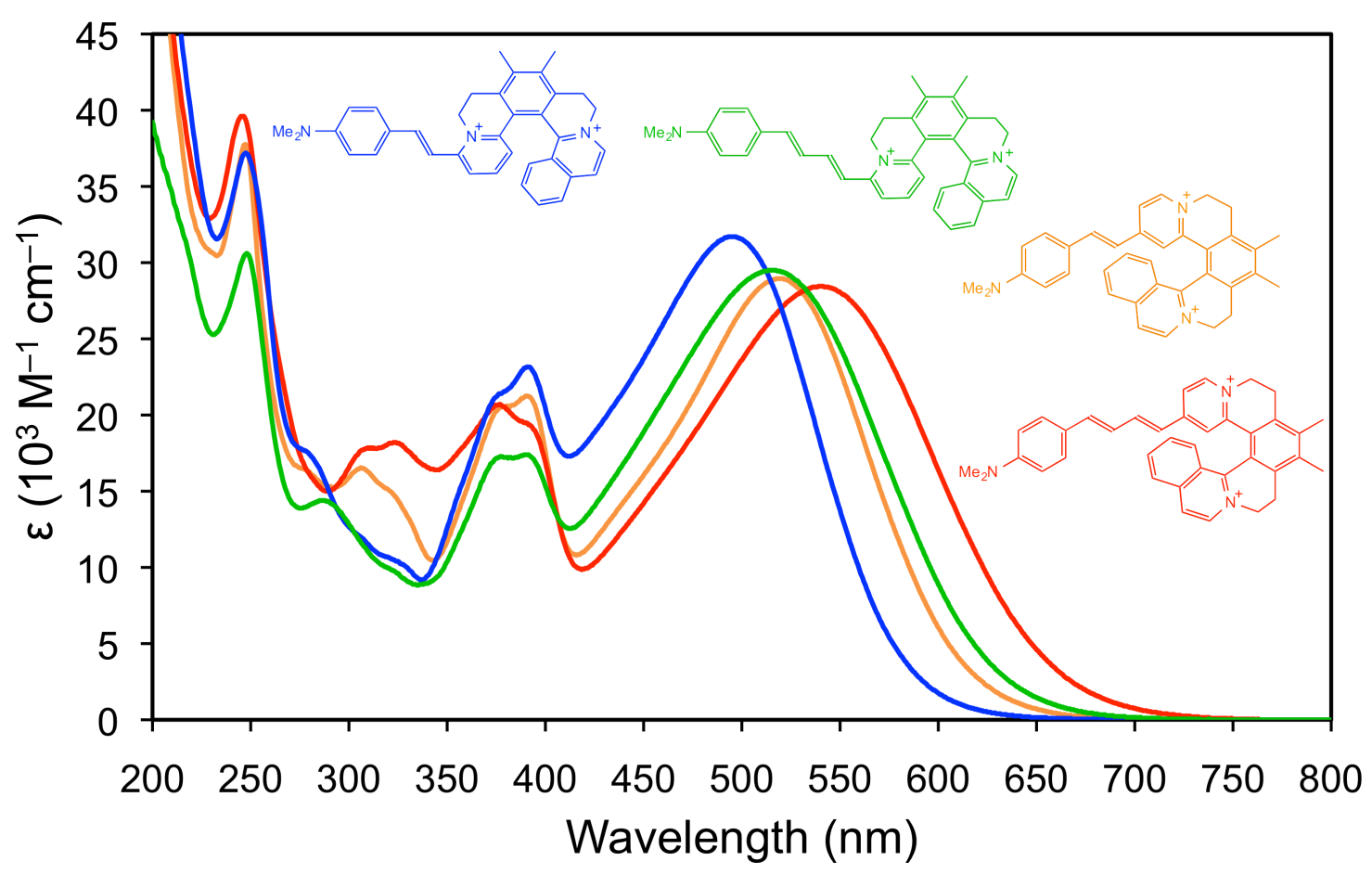

Figure 5. UV-vis absorption spectra of the Hq salts $[\mathbf{1 0}][\mathrm{TfO}]_{2}$ (gold), $[\mathbf{1 3}][\mathrm{TfO}]_{2}$ (red), $[\mathbf{1 7}][\mathrm{TfO}]_{2}$ (blue) and [18][TfO $]_{2}$ (green) in $\mathrm{MeCN}$ at $293 \mathrm{~K}$; note the red-shifts of the visible band as the $\pi$-conjugated system extends on moving from 10 to 13 or from 17 to 18 , and the relative constancy of the absorption in the $350-400 \mathrm{~nm}$ region. 
Table 1. ICT Absorption, Stark Spectroscopic and HRS data for Salts [1-18][TfO $]_{2}$ and [DAS]PF 6

\begin{tabular}{|c|c|c|c|c|c|c|c|c|c|c|}
\hline salt & $\begin{array}{l}\lambda_{\max }{ }^{a}(\mathrm{~nm}) \\
\left(\varepsilon, 10^{3} \mathrm{M}^{-1} \mathrm{~cm}^{-1}\right)\end{array}$ & $\begin{array}{l}E_{\max }{ }^{a} \\
(\mathrm{eV})\end{array}$ & $\begin{array}{l}\lambda_{\max }^{b} \\
(\mathrm{~nm})\end{array}$ & $\begin{array}{l}E_{\max }^{b} \\
(\mathrm{eV})\end{array}$ & $f_{\mathrm{os}}^{b, c}$ & $\begin{array}{l}\mu_{12}^{b, d} \\
\text { (D) }\end{array}$ & $\begin{array}{l}\Delta \mu_{12}^{b, e} \\
\text { (D) }\end{array}$ & $\begin{array}{l}\beta_{0}[\mathrm{~S}]^{f} \\
\left(10^{-30} \text { esu }\right)\end{array}$ & $\begin{array}{l}\beta_{800^{g}} \\
\left(10^{-30} \text { esu }\right)\end{array}$ & $\begin{array}{l}\beta_{0}[\mathrm{H}]^{h} \\
\left(10^{-30} \text { esu }\right)\end{array}$ \\
\hline$[\mathbf{1}][\mathrm{TfO}]_{2}$ & $413(25.9)$ & 3.00 & 412 & 3.01 & 0.43 & 6.2 & 14.4 & 74 & $207 \pm 19$ & $10 \pm 1$ \\
\hline$[2][\mathrm{TfO}]_{2}$ & $428(28.3)$ & 2.90 & 426 & 2.91 & 0.52 & 6.9 & 16.8 & 110 & $249 \pm 46$ & $26 \pm 5$ \\
\hline$[3][\mathrm{TfO}]_{2}$ & $446(33.6)$ & 2.78 & 445 & 2.79 & 0.56 & 7.3 & 15.4 & 122 & $254 \pm 47$ & $43 \pm 8$ \\
\hline \multirow[t]{3}{*}[4]{$[\mathrm{TfO}]_{2}$} & $396(28.2)$ & 3.13 & 427 & 2.90 & 0.07 & 2.5 & 15.4 & 14 & $121 \pm 13$ & $9 \pm 1$ \\
\hline & & & 407 & 3.05 & 0.17 & 3.9 & 13.6 & 26 & & \\
\hline & & & 383 & 3.24 & 0.11 & 3.0 & 6.0 & $6(46)$ & & \\
\hline \multirow[t]{3}{*}[5]{$[\mathrm{TfO}]_{2}$} & $417(33.2)$ & 2.97 & 433 & 2.86 & 0.15 & 3.7 & 14.7 & 28 & $197 \pm 21$ & $12 \pm 1$ \\
\hline & & & 412 & 3.01 & 0.17 & 3.9 & 12.8 & 26 & & \\
\hline & & & 384 & 3.23 & 0.21 & 4.2 & 0.0 & $0(54)$ & & \\
\hline \multirow[t]{3}{*}[6]{$[\mathrm{TfO}]_{2}$} & $436(34.5)$ & 2.84 & 455 & 2.73 & 0.23 & 4.7 & 15.8 & 54 & $199 \pm 8$ & $26 \pm 1$ \\
\hline & & & 428 & 2.90 & 0.34 & 5.6 & 13.0 & 56 & & \\
\hline & & & 382 & 3.25 & 0.35 & 5.3 & 8.5 & $28(138)$ & & \\
\hline \multirow[t]{3}{*}[7]{$[\mathrm{TfO}]_{2}$} & $420 \operatorname{sh}(24.9)$ & 2.95 & 438 & 2.83 & 0.11 & 3.2 & 12.1 & 18 & $158 \pm 17$ & $16 \pm 2$ \\
\hline & & & 414 & 3.00 & 0.17 & 3.9 & 10.8 & 22 & & \\
\hline & & & 392 & 3.16 & 0.10 & 2.9 & 4.5 & $4(44)$ & & \\
\hline \multirow[t]{3}{*}[8]{$[\mathrm{TfO}]_{2}$} & $433(29.1)$ & 2.86 & 452 & 2.74 & 0.14 & 3.7 & 18.0 & 38 & $208 \pm 23$ & $25 \pm 3$ \\
\hline & & & 422 & 2.94 & 0.28 & 5.0 & 17.4 & 58 & & \\
\hline & & & 392 & 3.16 & 0.11 & 3.0 & 5.2 & $6(102)$ & & \\
\hline \multirow[t]{3}{*}[9]{$[\mathrm{TfO}]_{2}$} & $448(31.1)$ & 2.77 & 472 & 2.63 & 0.22 & 4.7 & 18.2 & 68 & $202 \pm 22$ & $35 \pm 4$ \\
\hline & & & 444 & 2.79 & 0.16 & 3.9 & 18.0 & 42 & & \\
\hline & & & 419 & 2.96 & 0.22 & 4.4 & 15.0 & 40 (150) & & \\
\hline$[\mathbf{1 0}][\mathrm{TfO}]_{2}$ & $522(29.3)$ & 2.38 & 531 & 2.34 & 0.41 & 6.8 & 22.8 & 224 & $181 \pm 20$ & $72 \pm 8$ \\
\hline$[\mathbf{1 1}][\mathrm{TfO}]_{2}$ & $568(29.4)$ & 2.18 & 577 & 2.15 & 0.67 & 9.2 & 19.7 & 408 & $174 \pm 12$ & $88 \pm 6$ \\
\hline$[12][\mathrm{TfO}]_{2}$ & $514(28.8)$ & 2.41 & 531 & 2.34 & 0.42 & 6.9 & 30.0 & 300 & $284 \pm 27$ & $109 \pm 10$ \\
\hline$[\mathbf{1 3}][\mathrm{TfO}]_{2}$ & $541(28.5)$ & 2.29 & 554 & 2.24 & 0.43 & 6.8 & 36.6 & 430 & $315 \pm 34$ & $140 \pm 15$ \\
\hline$[\mathbf{1 4}][\mathrm{TfO}]_{2}$ & $599(29.6)$ & 2.07 & 594 & 2.09 & 0.62 & 8.9 & 27.6 & 580 & $254 \pm 23$ & $139 \pm 13$ \\
\hline$[\mathbf{1 5}][\mathrm{TfO}]_{2}{ }^{i}$ & $520(33.2)$ & 2.38 & 526 & 2.36 & 0.68 & 8.7 & 14.3 & 258 & $184 \pm 15$ & $73 \pm 6$ \\
\hline$[\mathbf{1 6}][\mathrm{TfO}]_{2}{ }^{i}$ & $539(34.9)$ & 2.30 & 549 & 2.26 & 0.96 & 10.6 & 25.6 & 658 & $302 \pm 32$ & $135 \pm 14$ \\
\hline$[\mathbf{1 7}][\mathrm{TfO}]_{2}{ }^{i}$ & $496(31.7)$ & 2.50 & 498 & 2.49 & 0.56 & 7.8 & 22.5 & 252 & $171 \pm 12$ & $57 \pm 4$ \\
\hline$[\mathbf{1 8}][\mathrm{TfO}]_{2}{ }^{i}$ & $516(29.5)$ & 2.40 & 533 & 2.33 & 0.82 & 9.7 & 21.1 & 424 & $401 \pm 43$ & $156 \pm 17$ \\
\hline$[\mathrm{DAS}] \mathrm{PF}_{6}{ }^{j}$ & $470(42.8)$ & 2.64 & 480 & 2.58 & 0.80 & 9.1 & 16.3 & 236 & $440 \pm 30$ & $110 \pm 7$ \\
\hline
\end{tabular}

${ }^{a}$ In MeCN at $295 \mathrm{~K} .{ }^{b}$ In PrCN at $77 \mathrm{~K}$; for $[4-9][\mathrm{TfO}]_{2}$, all data relate to the Gaussian fitting functions. ${ }^{c}$ For $[\mathbf{1 - 3}][\mathrm{TfO}]_{2}$ and $[\mathbf{1 0}-\mathbf{1 4}][\mathrm{TfO}]_{2}$, obtained from $\left(4.32 \times 10^{-9} \mathrm{M} \mathrm{cm}^{2}\right) A$ where $A$ is the numerically integrated area under the absorption peak; for [4-9][TfO $]_{2}$, obtained from $\left(4.60 \times 10^{-9} \mathrm{M} \mathrm{cm}^{2}\right) \varepsilon_{\max } \times f w_{1 / 2}$ where $\varepsilon_{\max }$ is the maximal molar extinction coefficient and $f w_{1 / 2}$ is the full width at half height (in wavenumbers). ${ }^{d}$ Calculated from eq $1 .{ }^{e}$ Calculated from $f_{\text {int }} \Delta \mu_{12}$ by using $f_{\text {int }}=1.33 .{ }^{f}$ Calculated from eq 2; for $[4-9]\left[\mathrm{TfO}_{2}\right.$, the total values are given in brackets. The quoted cgs units (esu) can be converted into SI units $\left(\mathrm{C}^{3} \mathrm{~m}^{3} \mathrm{~J}^{-2}\right)$ by dividing by $2.693 \times 10^{20}$, or into atomic units by dividing by $0.8640 \times 10^{-32} .{ }^{g}$ Obtained from HRS measurements with a $800 \mathrm{~nm}$ 


\section{Page 11 of 43}

The Journal of Physical Chemistry

$\mathrm{Ti}^{3+}$ :sapphire laser and MeCN solutions at $293 \mathrm{~K} .{ }^{h}$ Derived from $\beta_{800}$ by application of the two-state model. ${ }^{36,37 i}$ Data taken from ref $29 .{ }^{j}$ Data taken from refs 34 and 38 . 
Hyper-Rayleigh Scattering. We have used $800 \mathrm{~nm}$ femtosecond hyper-Rayleigh scattering (HRS) measurements ${ }^{35}$ to determine resonant $\beta$ values for $[\mathbf{1}-\mathbf{1 4}][\mathrm{TfO}]_{2}$ in $\mathrm{MeCN}$, and $\beta_{0}$ values have been estimated by using the two-state model. ${ }^{36,37}$ The results are listed in Table 1, along with the corresponding data reported previously for $[\mathbf{1 5}-\mathbf{1 8}][\mathrm{TfO}]_{2}{ }^{29}$ and the benchmark [DAS] $\mathrm{PF}_{6}{ }^{38}$ The results of DFT and TD-DFT calculations (see below) confirm that the new chromophores behave as essentially two-state systems, i.e. showing one low energy electronic transition that is expected to dominate the NLO response.

Within the three series of methoxy derivatives, $\beta_{0}[\mathrm{H}]$ increases in the orders $\mathbf{1}<\mathbf{2}<\mathbf{3}$, $\mathbf{4}<\mathbf{5}<\mathbf{6}$, and $\mathbf{7}<\mathbf{8}<\mathbf{9}$, consistent with the accompanying red-shifting of the low energy ICT band (see above) as the conjugated $\pi$-system extends. These $\beta_{0}[\mathrm{H}]$ values are relatively modest and significantly smaller than those of the analogous chromophores with dimethylamino substituents $\left(\beta_{0}[\mathrm{H}]=89\right.$ and $90 \times 10^{-30}$ esu, respectively for the $[5] \mathrm{Hq}$ and para-substituted [6]Hq naphthyl derivatives). ${ }^{29}$ The decreases in NLO response are due to the weaker electron donating strength of a methoxy group, as also evidenced by the ICT $E_{\max }$ values.

Within the $[6] \mathrm{Hq}$ amino-substituted series $[\mathbf{1 0}-\mathbf{1 4}][\mathrm{TfO}]_{2}, \beta_{0}[\mathrm{H}]$ increases in the order $10<11<12<13 \approx 14$. This trend is again largely due to extending the conjugated $\pi$-system, while the greater $\pi$-electron donating strength of the julolidinyl group when compared with 4(dimethylamino)phenyl, ${ }^{39}$ evident in the ICT energies translates into a larger $\beta_{0}[\mathrm{H}]$ response for $[\mathbf{1 1}][\mathrm{TfO}]_{2}$ vs $[\mathbf{1 0}][\mathrm{TfO}]_{2}$, but not for $[\mathbf{1 4}][\mathrm{TfO}]_{2}$ vs $[\mathbf{1 3}][\mathrm{TfO}]_{2}$. In fact, in the context of our previous studies, ${ }^{29,39}$ and the data derived from Stark spectroscopy (see below), the $\beta_{0}[\mathrm{H}]$ value determined for $[\mathbf{1 4}][\mathrm{TfO}]_{2}$ does appear to be anomalously low.

Within three out of five series with a given electron donor group, the ortho-substituted $[6] \mathrm{Hq}$ has a $\beta_{0}[\mathrm{H}]$ value significantly lower than its para-conjugated $[5] \mathrm{Hq}$ or [6] Hq analogues. This trend is consistent with the fact that the ortho-substituted chromophores have relatively higher values of $E_{\max }$ for the low energy absorption band (see above). The value for $[4][\mathrm{TfO}]_{2}$ is indistinguishable from that of $[\mathbf{1}][\mathrm{TfO}]_{2}$, while those of $[\mathbf{1 3}][\mathrm{TfO}]_{2},[\mathbf{1 6}][\mathrm{TfO}]_{2}$ and $[\mathbf{1 8}][\mathrm{TfO}]_{2}$ are not significantly different. 
Stark Spectroscopy. We have used Stark (electroabsorption) spectroscopy ${ }^{40,41}$ in PrCN glasses at $77 \mathrm{~K}$ to derive $\Delta \mu_{12}$ values for the low energy ICT bands of the salts [114] $[\mathrm{TfO}]_{2}$. These and other data measured under the same conditions are shown in Table 1, together with those for $[\mathbf{1 5}-\mathbf{1 8}][\mathrm{TfO}]_{2}{ }^{29}$ and $[\mathrm{DAS}] \mathrm{PF}_{6} \cdot{ }^{38}$ Representative UV-vis absorption and Stark spectra are shown in Figure 6.

For the methoxy-substituted chromophores in $[\mathbf{1 - 9}][\mathrm{TfO}]_{2}$, the ICT bands show very little change on moving from $\mathrm{MeCN}$ solutions to $\mathrm{PrCN}$ glasses. However, small red shifts are observed for all of the amino derivatives, except for $[\mathbf{1 4}][\mathrm{TfO}]_{2}$. Clearly, the amino species are more sensitive than their methoxy counterparts to environmental changes. When comparing the values of $\mu_{12}$ and $\Delta \mu_{12}$, it is appropriate to use totals for the former and averages for the latter in the cases when Gaussian deconvolution was used. Within each of the series $[\mathbf{1}-\mathbf{3}][\mathrm{TfO}]_{2},[\mathbf{4}-\mathbf{6}][\mathrm{TfO}]_{2}$ and $[\mathbf{7}-\mathbf{9}][\mathrm{TfO}]_{2}, \mu_{12}$ increases steadily, while $\Delta \mu_{12}$ does not show a consistent trend. Extending the $\pi$-conjugated system with an extra vinyl unit $(\mathbf{1} \rightarrow \mathbf{3}, \mathbf{4}$ $\rightarrow \mathbf{6}$, or $\mathbf{7} \rightarrow \mathbf{9}$ ) appears to increase $\Delta \mu_{12}$, but the difference is significant for $\mathbf{7}$ and $\mathbf{9}$ only. The same, logical trend is observed strongly also for the amino species $[\mathbf{1 0}-\mathbf{1 4}][\mathrm{TfO}]_{2}(\mathbf{1 0} \rightarrow \mathbf{1 3}$, or $11 \rightarrow \mathbf{1 4})$. The $\mu_{12}$ values for $[\mathbf{1 0}][\mathrm{TfO}]_{2},[\mathbf{1 2}][\mathrm{TfO}]_{2}$ and $[\mathbf{1 3}][\mathrm{TfO}]_{2}$ are essentially identical, while this parameter is increased significantly for the julolidinyl species $[\mathbf{1 1}][\mathrm{TfO}]_{2}$ and $[14]\left[\mathrm{TfO}_{2}\right.$. Comparing the data for the chromophore pairs 7/10, 8/12 and 9/13 shows that the amino derivatives always have smaller values of $\mu_{12}$, but much larger $\Delta \mu_{12}$ when compared with their methoxy analogues.

Within each of the series $[\mathbf{1}-\mathbf{3}][\mathrm{TfO}]_{2},[\mathbf{4}-\mathbf{6}][\mathrm{TfO}]_{2}$ and $[7-9][\mathrm{TfO}]_{2}$, the $\beta_{0}[\mathrm{~S}]$ values determined by using eq 2 increase steadily. Although in most cases the incremental differences are within the estimated error limit $( \pm 20 \%)$, the observation of a consistent trend for three separate series suggests that it is real. The $\beta_{0}[\mathrm{~S}]$ values for these methoxy species are all smaller than that derived for $[\mathrm{DAS}] \mathrm{PF}_{6}$, while the amino derivatives $[\mathbf{1 0}-\mathbf{1 4}][\mathrm{TfO}]_{2}$ mostly show NLO responses larger than that of this benchmark. Comparing the data for the three chromophore pairs $7 / \mathbf{1 0}, \mathbf{8} / \mathbf{1 2}$ and $\mathbf{9} / \mathbf{1 3}$ reveals that the $\beta_{0}[\mathrm{~S}]$ values of the amino derivatives are 3-5-fold larger than those of their methoxy counterparts. These increases are attributable 
to the combination of large decreases in $E_{\max }$ with increases in $\Delta \mu_{12}$, offsetting the accompanying decreases in $\mu_{12}$.

The estimated errors on $\beta_{0}[\mathrm{~S}]$ generally obscure any trend due to varying the Hq unit, but in the two series where the differences are significant $(\mathbf{1 3} / \mathbf{1 6} / \mathbf{1 8}$ and $\mathbf{1 / 4} / \mathbf{7})$, the [5]Hq has the largest value, while those for the ortho- and para-substituted [6]Hqs are indistinguishable. The trends in $\beta_{0}[\mathrm{~S}]$ largely match those shown by the HRS data, and the Stark results reinforce the suggestion that the $\beta_{0}[\mathrm{H}]$ value for $[\mathbf{1 4}][\mathrm{TfO}]_{2}$ is anomalously low (see above). The relatively large quadratic NLO responses determined mean that noncentrosymmetric crystalline materials incorporating these new Hq cations are attractive targets for potentially large bulk NLO effects. Although the methoxy-substituted compounds show weaker NLO behavior than their amino counterparts, greater visible transparency can be important for practical applications. 

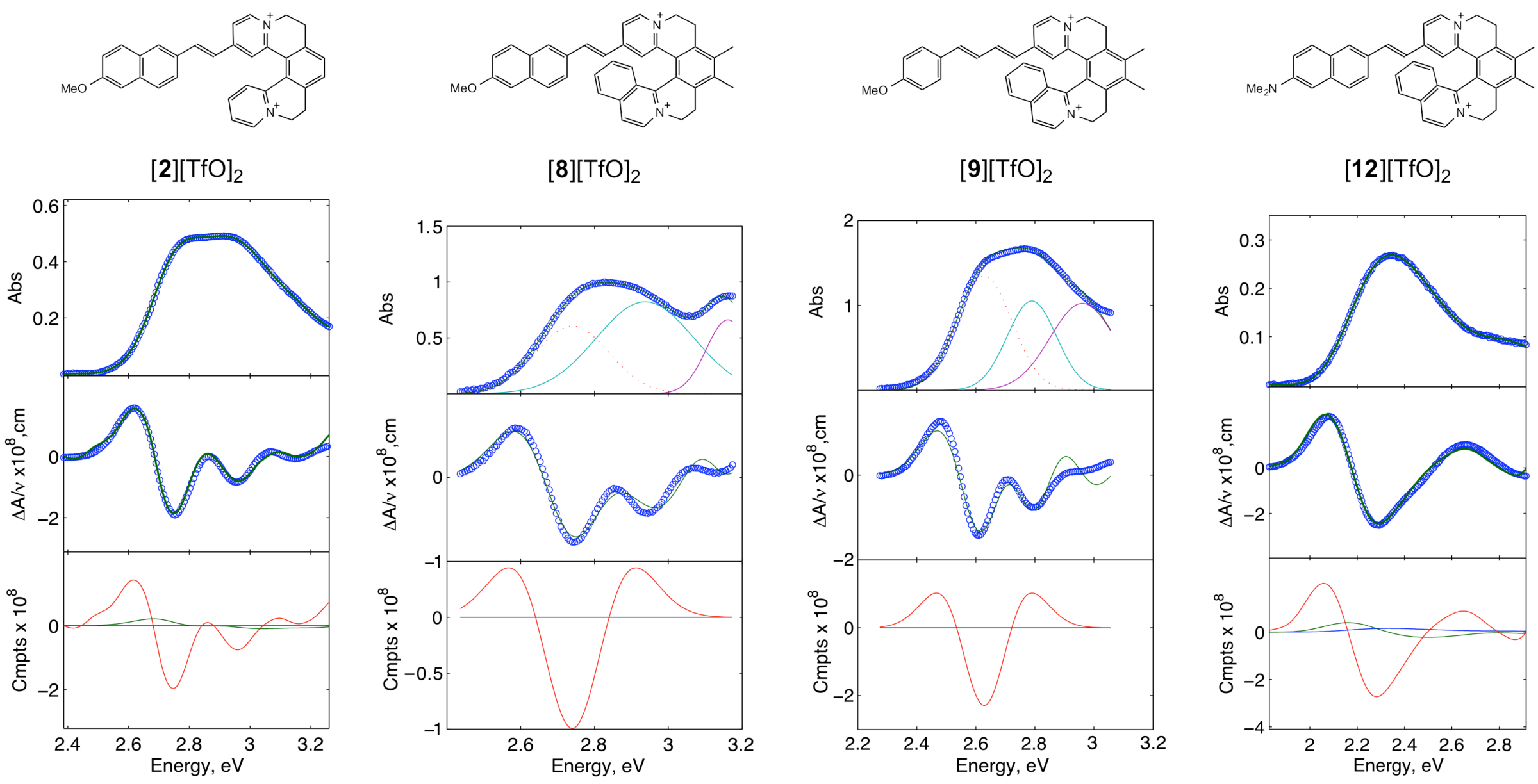

Figure 6. Spectra and calculated fits for the salts $[\mathbf{2}][\mathrm{TfO}]_{2},[\mathbf{8}][\mathrm{TfO}]_{2},[\mathbf{9}][\mathrm{TfO}]_{2}$ and $[\mathbf{1 2}][\mathrm{TfO}]_{2}$. Top panel: UV-vis absorption spectrum; middle panel: electroabsorption spectrum, experimental (blue) and fits (green) according to the Liptay equation; ${ }^{40}$ bottom panel: contribution of 0th (blue), 1st (green) and 2nd (red) derivatives of the absorption spectrum to the calculated fits. 
Theoretical Computations. In order to rationalize the experimental UV-vis absorption data and further probe the quadratic NLO properties, we have performed DFT and TD-DFT calculations on the new Hqs 10 and 13, and also on the previously reported 16 and 18. Selected published data calculated for $\mathbf{1 5}$ and $\mathbf{1 7}$ are also reproduced here to facilitate comparisons. This series of dications comprises three pairs with variations in the Hq unit and the length of the $\pi$-conjugated system. The Gaussian 09 suite of programs was used for all calculations, ${ }^{42}$ and data for the electronic transitions calculated in $\mathrm{MeCN}$ are summarized in the Supporting Information (Table S2), together with selected experimental data.

Initial studies with 16 used the $6-311 G(d)$ basis set with the functionals B3LYP, ${ }^{43}$ M06, ${ }^{44}$ or CAM-B3LYP. ${ }^{45}$ The simulated UV-vis absorption spectra (Supporting Information, Figure S15) show that CAM-B3LYP is clearly the best choice. B3LYP reproduces the main ICT band well, with only a slight blue-shift in its maximum, but this functional also predicts a relatively intense transition at higher wavelength $(678 \mathrm{~nm})$ which is notably absent from the experimental spectrum. M06 predicts two intense low energy absorptions, lying on either side of the peak observed with $\lambda_{\max }=538 \mathrm{~nm}$ in the experimental spectrum. In contrast, CAM-B3LYP models the intense visible band accurately, with a blueshift of only $6 \mathrm{~nm}$ (ca. $0.03 \mathrm{eV}$ ). Similar comparative studies with $\mathbf{1 5}$ lead to the same general conclusion, ${ }^{29}$ but CAM-B3LYP performs even better with 16. Therefore, this functional was used with the $6-311 \mathrm{G}(\mathrm{d})$ basis set for all subsequent calculations. The agreement between the geometric parameters obtained from X-ray crystallography and those predicted by DFT is generally very good (Supporting Information, Table S3); for 17, the discrepancy for bond distances is never larger than $0.04 \AA$, while the largest difference for bond angles is $1.9^{\circ}$. 
(a)

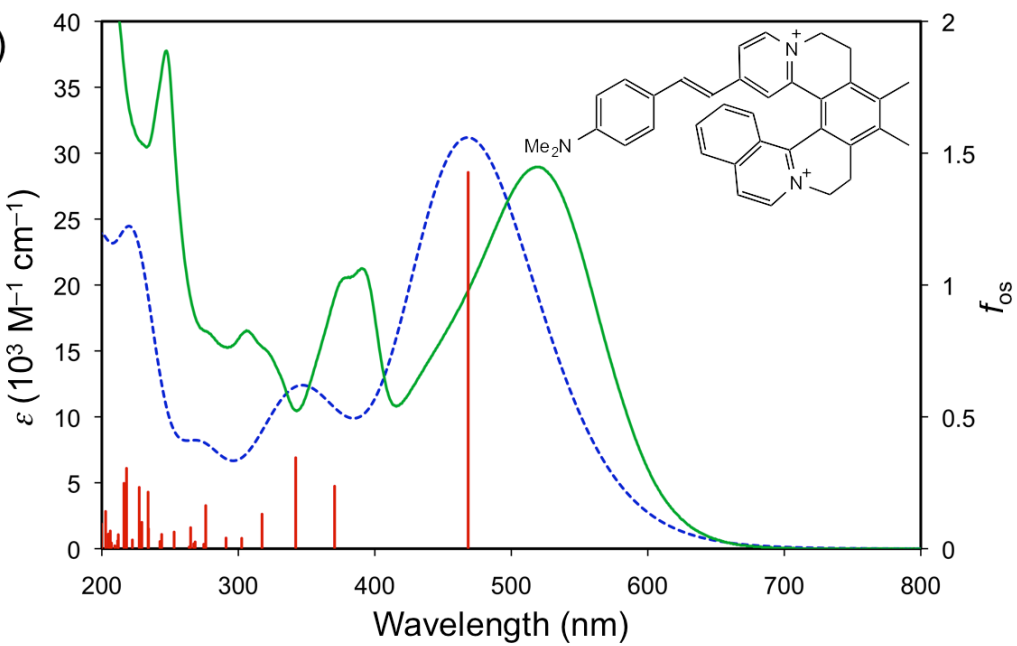

(b)

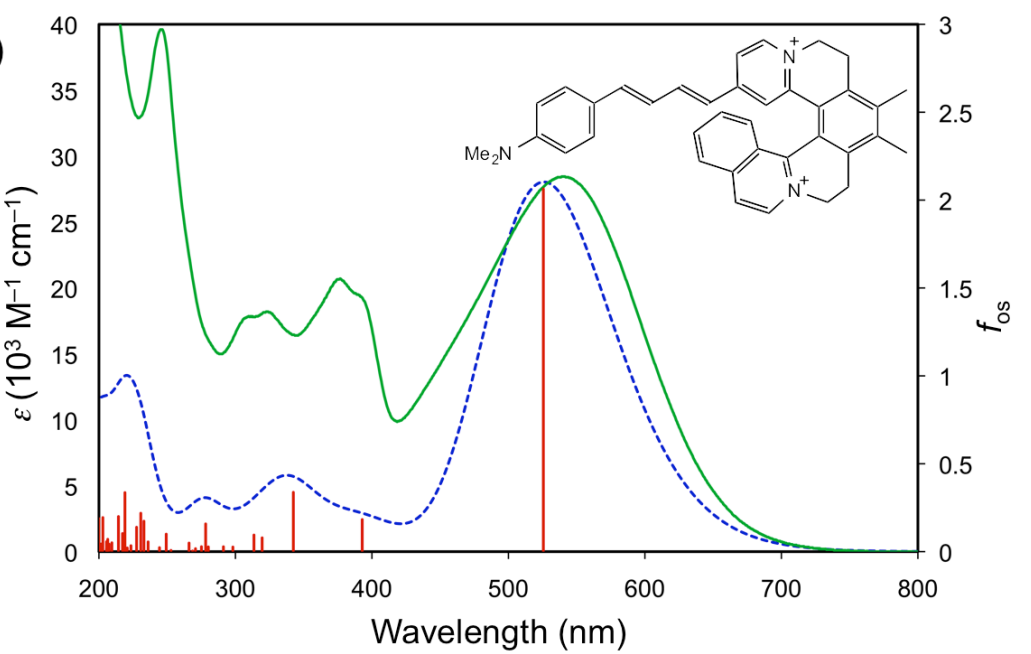

(c)

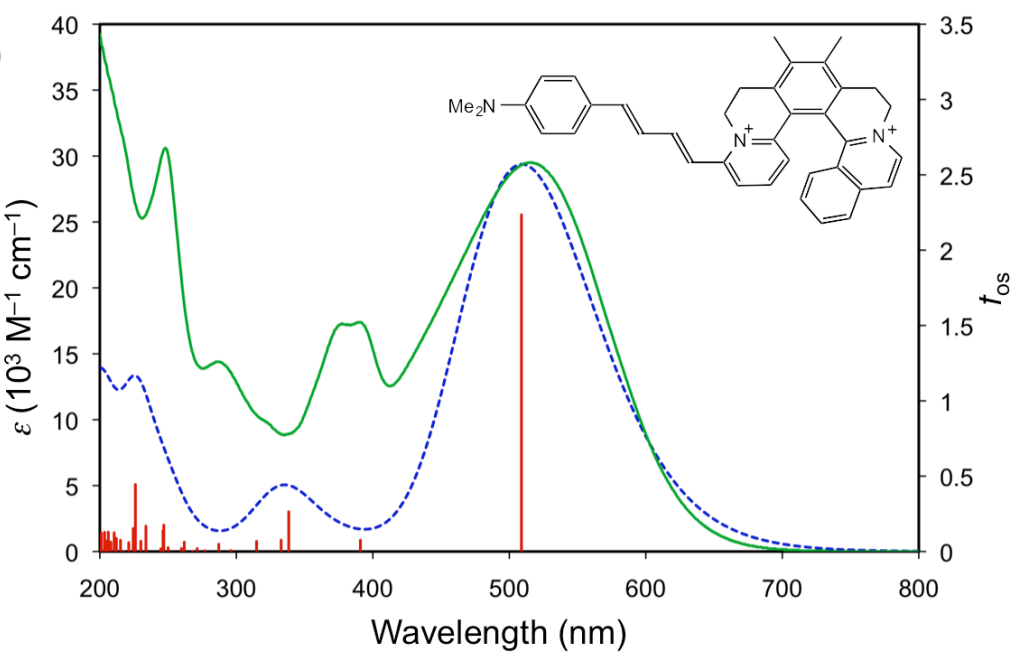

Figure 7. Experimental UV-vis absorption spectra of $[\mathbf{1 0}][\mathrm{TfO}]_{2}$ (a), $[\mathbf{1 3}][\mathrm{TfO}]_{2}$ (b) and $[\mathbf{1 8}][\mathrm{TfO}]_{2}$ (c) shown with the 6-311G(d)/CAM-B3LYP-calculated spectra for the Hqs in $\mathrm{MeCN}$ (blue dashed). The $\varepsilon$-axes refer to the experimental data only and the vertical axes of the calculated data are scaled to match the main experimental absorptions. The $f_{\text {os }}$-axes refer to the individual calculated transitions (red). 
The UV-vis absorption spectra for 10, 13 and 18 obtained by using 6-311G(d)/CAMB3LYP are shown in Figure 7, along with the measured data. In each case, the predicted $\lambda_{\max }$ value for the visible band is lower than that measured; the differences are only $6 \mathrm{~nm}$ (ca. 0.03 $\mathrm{eV}$ ) for $\mathbf{1 8}$ and $15 \mathrm{~nm}$ (ca. $0.07 \mathrm{eV}$ ) for $\mathbf{1 3}$, but relatively large at $54 \mathrm{~nm}$ (ca. $0.3 \mathrm{eV}$ ) for $\mathbf{1 0}$ (Supporting Information, Table S2). It is notable that within each of the pairs 10/13, 15/16 and $\mathbf{1 7 / 1 8}$, the visible $\lambda_{\max }$ value is predicted with considerably greater accuracy for the Hqs with extended $\pi$-conjugated systems, i.e. 13, 16 and 18 .

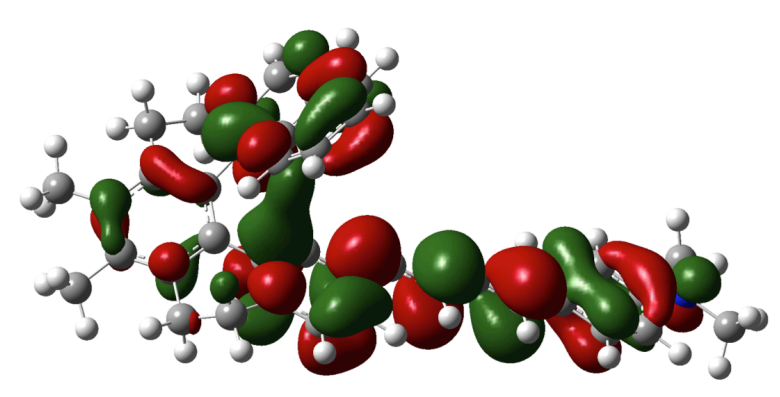

LUMO+1 $-0.23 \mathrm{eV}$

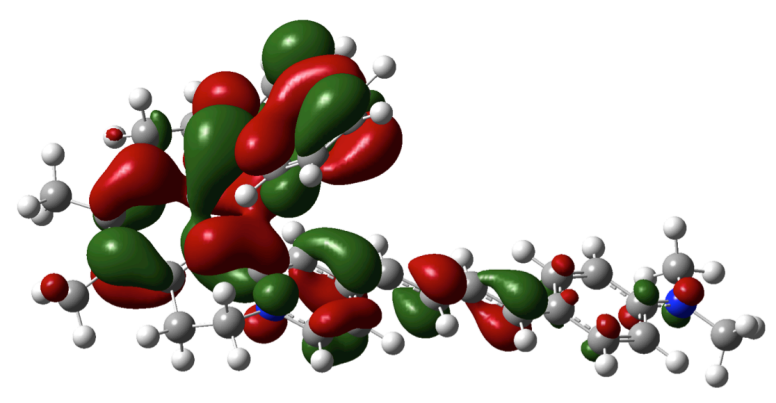

$$
\text { LUMO }-0.25 \mathrm{eV}
$$

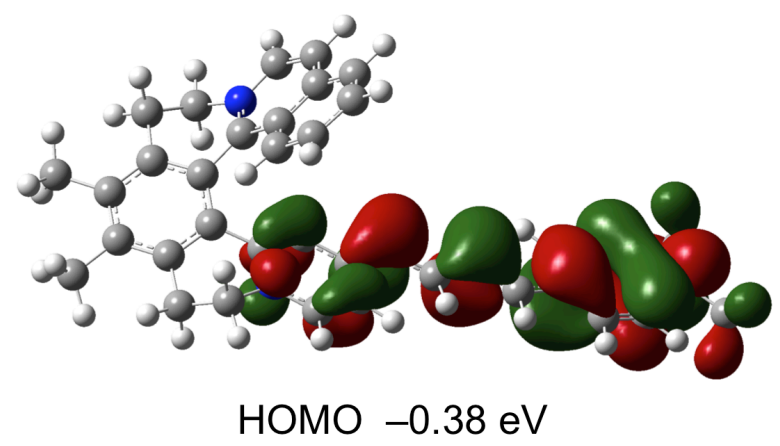

Figure 8. 6-311G(d)/CAM-B3LYP-derived contour surface diagrams of the main MOs involved in the electronic transition at $526 \mathrm{~nm}$ in the $\mathrm{Hq} \mathbf{1 3}$. 
The frontier MOs of 10, 13, 16 and 18 are depicted in the Supporting Information (Figures S16-S19), and those involved in the transition giving rise to the visible absorption band in $\mathbf{1 3}$ are shown in Figure 8. In all of the Hqs studied, the intense visible band contains a single transition which has a dominant contribution from HOMO $\rightarrow$ LUMO in all cases except for 17. A HOMO $\rightarrow \mathrm{LUMO}+1$ contribution is significant also in most cases, and is even a little more important than HOMO $\rightarrow$ LUMO in 17. The HOMO is based largely on the 4-(dimethylamino)phenyl and vinyl/butadienyl units, while the LUMO is located mostly on the $\mathrm{Hq}$ fragment, and the LUMO+1 extends over most of the molecule (Figure 8). These results confirm the expected ICT character of the visible absorption bands. Of the numerous relatively weak transitions calculated to appear in the UV region, many also display significant ICT character due to involvement of the donor orbitals HOMO-1 and HOMO-2.

The optimized molecular structures of 10, 13, 16 and 18 are included in the Supporting Information (Figure S20), showing their orientations with respect to the Cartesian axes. Static first hyperpolarizabilities calculated in the gas phase and in $\mathrm{MeCN}$ for these Hqs and also for $\mathbf{1 5}$ and $\mathbf{1 7 ^ { 2 9 }}$ are shown in Table S4. As for the related Hqs studied previously, ${ }^{29}$ the $x$-axis in 10, 13, 16 and 18 is aligned approximately with the dipole of the (extended) stilbazolium unit (Supporting Information, Figure S20). Therefore, the tensor components $\beta_{x x x}$ and $\beta_{x}$ are dominant, while the largest "off-diagonal" contributions come from $\beta_{x x y}$ and $\beta_{x x z}$ (Supporting Information, Table S4).

In each case, $\beta_{\text {tot }}$ increases markedly on moving from the gas phase to $\mathrm{MeCN}$, as found in previous related studies. ${ }^{29}$ In keeping with the data obtained via HRS or Stark spectroscopy (Table 1), $\beta_{\text {tot }}$ increases substantially with extension of the $\pi$-conjugated system within each of the pairs $(\mathbf{1 0} \rightarrow \mathbf{1 3}, \mathbf{1 5} \rightarrow \mathbf{1 6}$, or $\mathbf{1 7} \rightarrow \mathbf{1 8})$. With respect to varying the Hq fragment within the two series 10/15/17 and 13/16/18, $\beta_{\text {tot }}$ is similar for the $[5] \mathrm{Hq}$ and the para-conjugated $[6] \mathrm{Hq}$, while the ortho-substituted $[6] \mathrm{Hq}$ has a smaller value (Supporting Information, Table S4). This trend is consistent with the measured and predicted $E_{\max }$ values for the visible absorption bands, in the context of the two-state model, i.e., $\beta_{0} \propto 1 /\left(E_{\max }\right)^{2}$, eq 2 (see below). ${ }^{35,36}$ It is also in at least partial agreement with the experimentally derived $\beta_{0}$ values (see above). 


\section{CONCLUSIONS}

We have synthesized and characterized a large series of new Hq dyes with electron-donating substituents. Their UV-vis absorption spectra show one intense low energy band attributed to ICT transitions, with additional higher energy features. Single crystal X-ray structures of the solvated salt $[2]\left[\mathrm{PF}_{6}\right]_{2} \cdot \mathrm{MeCN}$ and $[6]\left[\mathrm{TfO}_{2}\right.$ reveal centrosymmetric packing arrangements in the respective space groups $P b c a$ and $P \overline{1} .800 \mathrm{~nm}$ HRS measurements in MeCN reveal moderate-to-large values of $\beta_{0}$, with substantial enhancements for the amino derivatives over their methoxy counterparts. The molecular quadratic NLO response also increases when the $\pi$-conjugated system is extended. These trends are verified by the $\beta_{0}$ values derived indirectly from Stark spectroscopy in PrCN at $77 \mathrm{~K}$. TD-DFT calculations on selected chromophores give relatively good agreement between predicted and measured UV-vis absorption spectra when using the CAM-B3LYP functional with the 6-311G(d) basis set. The ICT character of the low energy absorptions is confirmed by the DFT and TD-DFT results. The $\beta_{\text {tot }}$ values predicted via DFT agree broadly with the $\beta_{0}$ data from HRS and Stark measurements, and the ICT energies from TD-DFT correlate with $\beta_{\text {tot }}$ in the context of the two-state model. Considering the theoretical and experimental results together indicates that para-conjugation between $\mathrm{Hq}$ and electron donor fragments is ideal, and there is no benefit with respect to the molecular quadratic NLO response of extending the Hq unit. The new Hqs described extend greatly the available range of crystallizable helically chiral dicationic chromophores with relatively large $\beta_{0}$ responses. 


\section{EXPERIMENTAL SECTION}

General Methods and Materials. Liquids and solutions were transferred via needle and syringe under inert atmosphere unless stated otherwise. Knoevenagel condensations were run in vessels covered with Alufoil in order to prevent prolonged exposure of the dicationic dyes to ambient light. TLC analysis was performed on silica gel 60 plates $\left(\mathrm{F}_{254}\right.$-coated aluminum sheets), with visualization by UV lamp (254/365 nm) and/or chemical staining with $\mathrm{KMnO}_{4}\left[\mathrm{KMnO}_{4}\left(1 \%\right.\right.$ aq), $\mathrm{Na}_{2} \mathrm{CO}_{3}(2 \%$ aq) $]$. Stoddart's magic mixture ${ }^{46}[\mathrm{MeOH} / \mathrm{aq}$ $\mathrm{NH}_{4} \mathrm{Cl}(2 \mathrm{M}) / \mathrm{MeNO}_{2}$ 7:2:1] was used as eluent. NMR spectra were measured at $600 \mathrm{MHz}$ for ${ }^{1} \mathrm{H}$ and $151 \mathrm{MHz}$ for ${ }^{13} \mathrm{C}$. All shifts were referenced to residual solvent signals $\left(\delta_{\mathrm{H}}=2.09 \mathrm{ppm}\right.$ and $\delta_{\mathrm{C}}=29.80 \mathrm{ppm}$ in $\left(\mathrm{CD}_{3}\right)_{2} \mathrm{CO} ; \delta_{\mathrm{H}}=1.94 \mathrm{ppm}$ and $\delta_{\mathrm{C}}=118.26 \mathrm{ppm}$ in $\left.\mathrm{CD}_{3} \mathrm{CN}\right)$, and are quoted with respect to TMS. Mass spectra were obtained using the electrospray (+ mode) ionization technique. The mobile phase consisted of $\mathrm{MeOH} /$ water (9:1) with a flow rate of

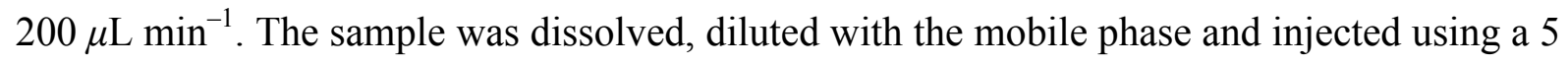
$\mu \mathrm{L}$ loop. Spray voltage, capillary voltage, tube lens voltage and capillary temperature were $5.5 \mathrm{kV}, 5 \mathrm{~V}, 80 \mathrm{~V}$ and $275^{\circ} \mathrm{C}$, respectively. The bis-triflate salts of the methyl-substituted $\mathrm{Hq}$ precursors I-III were prepared via published procedures, ${ }^{28,29,31}$ and $\mathrm{MeOH}$ was distilled from $\mathrm{Mg} / \mathrm{I}_{2}$ as described previously. ${ }^{29}$ All other solvents, starting materials and reagents were obtained from commercial suppliers and used as received.

Synthesis of (E)-2-(4-Methoxystyryl)-6,7,10,11-tetrahydrodipyrido[2,1- $a: 1^{\prime}, 2^{\prime}$ $k][2,9]$ phenanthroline-5,12-diium Trifluoromethanesulfonate $\quad\left([1]\left[\mathrm{TfO}_{2}\right) . \quad[5] \mathrm{Hq}\right.$ precursor $[\mathbf{I}][\mathrm{TfO}]_{2}(50 \mathrm{mg}, 0.084 \mathrm{mmol})$ and 4-methoxybenzaldehyde $(31 \mu \mathrm{L}, 35 \mathrm{mg}, 0.255$ mmol, 3.0 equiv) were charged into a Schlenk flask and placed under Ar. Dry $\mathrm{MeOH}$ (3.0 $\mathrm{mL}$ ) was added, followed by pyrrolidine ( $82 \mu \mathrm{L}, 71 \mathrm{mg}, 0.998 \mathrm{mmol}, 11.9$ equiv). The reaction mixture was stirred at RT for $1.5 \mathrm{~h}$ and monitored by TLC. The reaction was quenched by adding $\mathrm{Et}_{2} \mathrm{O}(10 \mathrm{~mL})$ and a yellow solid precipitated. The suspension was sonicated for $2 \mathrm{~min}$, then centrifuged and the supernatant discarded. The solid was further purified by precipitation from $\mathrm{MeOH}(1.0 \mathrm{~mL})$ with $\mathrm{Et}_{2} \mathrm{O}(10 \mathrm{~mL})$. The suspension was sonicated and centrifuged, and the supernatant removed. This dissolution-precipitation 
procedure was repeated twice more. After drying in a vacuum, the pure product was obtained as a yellow solid. Yield: $54 \mathrm{mg}(89 \%) .{ }^{1} \mathrm{H}$ NMR $\left(\mathrm{CD}_{3} \mathrm{CN}\right): \delta 3.17-3.41(\mathrm{~m}, 4 \mathrm{H}), 3.83(\mathrm{~s}, 3 \mathrm{H})$, 4.58-5.01 (m, 4H), 6.91-7.08 (m, 3H), $7.46(\mathrm{~d}, J=16.3 \mathrm{~Hz}, 1 \mathrm{H}), 7.55(\mathrm{~d}, J=8.8 \mathrm{~Hz}, 2 \mathrm{H})$, $7.71(\mathrm{~s}, 2 \mathrm{H}), 7.83(\mathrm{~d}, J=2.0 \mathrm{~Hz}, 1 \mathrm{H}), 7.87-7.94(\mathrm{~m}, 2 \mathrm{H}), 8.05(\mathrm{dd}, J=1.4,8.2 \mathrm{~Hz}, 1 \mathrm{H}), 8.18$ $(\mathrm{td}, J=1.4,8.0 \mathrm{~Hz}, 1 \mathrm{H}), 8.59(\mathrm{~d}, J=6.7 \mathrm{~Hz}, 1 \mathrm{H}), 8.82-8.88(\mathrm{~m}, 1 \mathrm{H}) .{ }^{13} \mathrm{C} \mathrm{NMR}\left(\mathrm{CD}_{3} \mathrm{CN}\right): \delta$ $28.1,28.5,54.8,56.2,56.3,115.8,121.1,122.2$, 127.0, 127.1, 127.5, 127.5, 128.6, 130.9, $131.1,133.3,133.6,141.5,141.6,142.3,145.7,145.9,147.0,147.0,148.0,154.9,163.0$. Elemental analysis: (\%) calcd for $\left[\mathrm{C}_{31} \mathrm{H}_{26} \mathrm{~F}_{6} \mathrm{~N}_{2} \mathrm{O}_{7} \mathrm{~S}_{2}\right] \mathrm{C} 51.95$, H 3.66, N 3.91; found C 51.85, H 3.60, N 3.70. IR (KBr): $\tilde{v}\left(\mathrm{~cm}^{-1}\right)$ 3085, 2929, 2851, 1620, 1593, 1515, 1440, 1427, 1259, 1257, 1226, 1200, 1175, 1161, 1031, 841, 639, 575. MS (ESI): $m / z(\%) 567.3\left[\left(\mathrm{M}-\mathrm{TfO}^{-}\right)^{+}\right]$ (26), $417.3\left[\left(\mathrm{M}-2 \mathrm{TfO}^{-}-\mathrm{H}\right)^{+}\right](100)$. HRMS (ESI): $m / z$ calcd for $\left[\left(\mathrm{M}-\mathrm{TfO}^{-}\right)^{+}\right]$ $\left(\mathrm{C}_{30} \mathrm{H}_{26} \mathrm{O}_{4} \mathrm{~N}_{2} \mathrm{~F}_{3} \mathrm{~S}\right)$ 567.15599; found 567.15568.

Synthesis of $\quad(E)-2-(2-(6-M e t h o x y n a p h t h a l e n-2-y l) v i n y l)-6,7,10,11-$ tetrahydrodipyrido[2,1-a:1',2'-k][2,9]phenanthroline-5,12-diium

Trifluoromethanesulfonate $\left([2][\mathbf{T f O}]_{2}\right)$. This compound was prepared and purified in a manner similar to $[\mathbf{1}][\mathrm{TfO}]_{2}$ by using $[\mathbf{I}][\mathrm{TfO}]_{2}$ (69 $\left.\mathrm{mg}, 0.115 \mathrm{mmol}\right)$, 6-methoxy-2naphthylaldehyde (44 mg, $0.236 \mathrm{mmol}, 2.1$ equiv), dry $\mathrm{MeOH}(3.0 \mathrm{~mL})$, and pyrrolidine (115 $\mu \mathrm{L}, 100 \mathrm{mg}, 1.40 \mathrm{mmol}, 12.2$ equiv). The reaction time was $2 \mathrm{~h}$. The addition of $\mathrm{Et}_{2} \mathrm{O}$ (20 $\mathrm{mL})$ was followed by three reprecipitations from $\mathrm{MeOH}(3.0 \mathrm{~mL})$ with $\mathrm{Et}_{2} \mathrm{O}(20 \mathrm{~mL})$ to give a light orange solid. Yield: $81 \mathrm{mg}(92 \%) .{ }^{1} \mathrm{H}$ NMR $\left(\left(\mathrm{CD}_{3}\right)_{2} \mathrm{CO}\right): \delta 3.52-3.61(\mathrm{~m}, 4 \mathrm{H}), 3.98(\mathrm{~s}$, $3 \mathrm{H}), 5.00(\mathrm{dt}, J=5.8,12.8 \mathrm{~Hz}, 1 \mathrm{H}), 5.17-5.22(\mathrm{~m}, 1 \mathrm{H}), 5.20-5.31(\mathrm{~m}, 2 \mathrm{H}), 7.23(\mathrm{dd}, J=2.6$, $8.9 \mathrm{~Hz}, 1 \mathrm{H}), 7.37$ (d, $J=2.6 \mathrm{~Hz}, 1 \mathrm{H}), 7.47(\mathrm{~d}, J=16.3 \mathrm{~Hz}, 1 \mathrm{H}), 7.83(\mathrm{~d}, J=7.8 \mathrm{~Hz}, 1 \mathrm{H}), 7.84$ $(\mathrm{d}, J=7.8 \mathrm{~Hz}, 1 \mathrm{H}), 7.88(\mathrm{dd}, J=0.6,16.3 \mathrm{~Hz}, 1 \mathrm{H}), 7.88(\mathrm{bd}, J=8.9 \mathrm{~Hz}, 1 \mathrm{H}), 7.90(\mathrm{~d}, J=7.8$ $\mathrm{Hz}, 1 \mathrm{H}), 8.11$ (bs, 2H), 8.14 (ddd, $J=1.5,6.2,7.8 \mathrm{~Hz}, 1 \mathrm{H}), 8.34$ (ddd, $J=0.4,2.0,6.7 \mathrm{~Hz}$, $1 \mathrm{H}), 8.41(\mathrm{ddd}, J=1.5,7.8,8.3 \mathrm{~Hz}, 1 \mathrm{H}), 8.42(\mathrm{~d}, J=2.0 \mathrm{~Hz}, 1 \mathrm{H}), 8.56(\mathrm{dd}, J=1.5,8.3 \mathrm{~Hz}$, $1 \mathrm{H}), 9.07$ (bd, $J=6.3 \mathrm{~Hz}, 1 \mathrm{H}), 9.27$ (ddq, $\left.J=0.7,6.2 \mathrm{~Hz}, 1 \mathrm{H}) .{ }^{13} \mathrm{C} \mathrm{NMR}\left(\mathrm{CD}_{3}\right)_{2} \mathrm{CO}\right): \delta 28.2$, 28.6, 54.9, 55.8, 56.3, 107.0, 120.3, 121.7, 123.0, 125.5, 127.3, 127.4, 127.7, 127.9, 128.4, $129.6,130.8,130.9,131.1,131.5,133.1,133.4,136.9,141.6,141.7,142.4,145.5,146.0$, 147.4, 147.5, 148.1, 154.6, 160.1. Elemental analysis: (\%) calcd for $\left[\mathrm{C}_{35} \mathrm{H}_{28} \mathrm{~F}_{6} \mathrm{~N}_{2} \mathrm{O}_{7} \mathrm{~S}_{2} \cdot \mathrm{H}_{2} \mathrm{O}\right] \mathrm{C}$ 
53.57, H 3.85, N 3.57; found C 53.72, H 3.64, N 3.39. IR (KBr): $\tilde{v}\left(\mathrm{~cm}^{-1}\right)$ 3083, 2846, 1607 , 1596, 1511, 1438, 1393, 1261, 1164, 1125, 1030, 638, 573, 518, 478. MS (ESI): $m / z(\%)$ $617.3\left[\left(\mathrm{M}-\mathrm{TfO}^{-}\right)^{+}\right](48), 467.3\left[\left(\mathrm{M}-2 \mathrm{TfO}^{-}-\mathrm{H}\right)^{+}\right](37), 234.1\left[\left(\mathrm{M}-2 \mathrm{TfO}^{-}\right)^{2+}\right](100)$. HRMS (ESI): $m / z$ calcd for $\left[\left(\mathrm{M}-\mathrm{TfO}^{-}\right)^{+}\right]\left(\mathrm{C}_{34} \mathrm{H}_{28} \mathrm{O}_{4} \mathrm{~N}_{2} \mathrm{~F}_{3} \mathrm{~S}\right)$ 617.17164; found 617.17170. Metathesis to the $\mathrm{PF}_{6}^{-}$salt was achieved by precipitation from an acetone solution with aq $\mathrm{NH}_{4} \mathrm{PF}_{6}$, followed by washing with water and drying under vacuum. Crystals suitable for $\mathrm{X}$ ray diffraction analysis were grown by slow diffusion of $\left({ }^{i} \mathrm{Pr}\right)_{2} \mathrm{O}$ vapor into a MeCN solution at room temperature in the dark over $8-10 \mathrm{~d}$.

Synthesis of 2-((1E,3E)-4-(4-Methoxyphenyl)buta-1,3-dien-1-yl)-6,7,10,11tetrahydrodipyrido[2,1-a:1',2'-k][2,9]phenanthroline-5,12-diium

Trifluoromethanesulfonate $\left([3][\mathbf{T f O}]_{2}\right)$. This compound was prepared and purified in a manner similar to $[\mathbf{2}][\mathrm{TfO}]_{2}$ by using $[\mathbf{I}][\mathrm{TfO}]_{2} \quad(71 \quad \mathrm{mg}, \quad 0.119 \mathrm{mmol})$, 4methoxycinnamaldehyde (39 mg, $0.240 \mathrm{mmol}, 2$ equiv), dry $\mathrm{MeOH}(3.0 \mathrm{~mL})$ and pyrrolidine (119 $\mu \mathrm{L}, 103 \mathrm{mg}, 1.45 \mathrm{mmol}, 12.2$ equiv). An orange solid was obtained. Yield: $56 \mathrm{mg}$ (64\%). ${ }^{1} \mathrm{H}$ NMR $\left(\left(\mathrm{CD}_{3}\right)_{2} \mathrm{CO}\right): \delta 3.54-3.61(\mathrm{~m}, 4 \mathrm{H}), 3.87(\mathrm{~s}, 3 \mathrm{H}), 4.94-5.02(\mathrm{~m}, 1 \mathrm{H}), 5.13-$ $5.18(\mathrm{~m}, 1 \mathrm{H}), 5.17-5.22(\mathrm{~m}, 1 \mathrm{H}), 5.27-5.32(\mathrm{~m}, 1 \mathrm{H}), 6.75(\mathrm{~d}, J=15.4 \mathrm{~Hz}, 1 \mathrm{H}), 6.98(\mathrm{ddd}, J=$ 0.6, 10.3, 15.4 Hz, 1H), 6.98-7.01 (m, 2H), 7.04 (d, $J=15.4 \mathrm{~Hz}, 1 \mathrm{H}), 7.53-7.55(\mathrm{~m}, 2 \mathrm{H})$, $7.56(\mathrm{dd}, J=10.3,15.4 \mathrm{~Hz}, 1 \mathrm{H}), 7.91(\mathrm{~s}, 2 \mathrm{H}), 8.15(\mathrm{dd}, J=2.0,6.7 \mathrm{~Hz}, 1 \mathrm{H}), 8.16$ (ddd, $J=$ $1.4,6.2,7.6 \mathrm{~Hz}, 1 \mathrm{H}), 8.27(\mathrm{~d}, J=2.0 \mathrm{~Hz}, 1 \mathrm{H}), 8.43(\mathrm{dt}, J=1.3,8.0 \mathrm{~Hz}, 1 \mathrm{H}), 8.57$ (dd, $J=1.4$, $8.2 \mathrm{~Hz}, 1 \mathrm{H}), 9.01(\mathrm{~d}, J=6.7 \mathrm{~Hz}, 1 \mathrm{H}), 9.29$ (bdd, $J=1.4,6.2,7.6 \mathrm{~Hz}, 1 \mathrm{H}) .{ }^{13} \mathrm{C} \mathrm{NMR}$ $\left(\left(\mathrm{CD}_{3}\right)_{2} \mathrm{CO}\right): \delta 28.3,28.7,54.8,55.7,56.3,115.3,121.8,126.1,126.4,127.2,127.3,127.5$, $127.8,129.8,129.9,130.9,133.1,133.4,141.6,141.7,142.1,143.6,145.5,146.0,147.2$, 147.4, 148.2, 154.5, 161.9. Elemental analysis: (\%) calcd for $\left[\mathrm{C}_{33} \mathrm{H}_{28} \mathrm{~F}_{6} \mathrm{~N}_{2} \mathrm{O}_{7} \mathrm{~S}_{2}\right] \mathrm{C} 53.37, \mathrm{H}$ 3.80, N 3.77; found C 53.27, H 3.73, N 3.51. IR (KBr): $\tilde{v}\left(\mathrm{~cm}^{-1}\right) 1635,1626,1610,1587$, $1511,1440,1425,1304,1280,1259,1225,1215,1150,1030,842,638$. MS (ESI): $m / z(\%)$ $593.2\left[\left(\mathrm{M}-\mathrm{TfO}^{-}\right)^{+}\right](11), 443.2\left[\left(\mathrm{M}-2 \mathrm{TfO}^{-}-\mathrm{H}\right)^{+}\right](52), 222.1\left[\left(\mathrm{M}-2 \mathrm{TfO}^{-}\right)^{2+}\right](100)$. HRMS (ESI): $m / z$ calcd for $\left[\left(\mathrm{M}-\mathrm{TfO}^{-}\right)^{+}\right]\left(\mathrm{C}_{32} \mathrm{H}_{28} \mathrm{~F}_{3} \mathrm{~N}_{2} \mathrm{O}_{4} \mathrm{~S}\right)$ 593.173164; found 593.173167.

Synthesis of $\quad(E)-11-(4-M e t h o x y s t y r y l)-6,7-d i m e t h y l-4,5,8,9-$ tetrahydroisoquinolino[1,2-a]pyrido[1,2-k][2,9]phenanthroline-3,10-diium 
Trifluoromethanesulfonate $\left([4][\mathbf{T f O}]_{2}\right)$. This compound was prepared and purified in a manner similar to $[\mathbf{1}][\mathrm{TfO}]_{2}$ by using $[6] \mathrm{Hq}$ precursor $[\mathbf{I I I}][\mathrm{TfO}]_{2}(35 \mathrm{mg}, 0.052 \mathrm{mmol}), 4-$ methoxybenzaldehyde (352 mg, $2.59 \mathrm{mmol}, 50$ equiv), dry $\mathrm{MeOH}(3.5 \mathrm{~mL})$ and pyrrolidine (53 $\mu \mathrm{L}, 46 \mathrm{mg}, 0.647 \mathrm{mmol}, 12.5$ equiv). The reaction time was $30 \mathrm{~min}$. The addition of $\mathrm{Et}_{2} \mathrm{O}$ $(70 \mathrm{~mL})$ was followed by three reprecipitations from $\mathrm{MeOH}(2.0 \mathrm{~mL})$ with $\mathrm{Et}_{2} \mathrm{O}(30 \mathrm{~mL})$ to give a yellow solid. Yield: $28 \mathrm{mg}(69 \%) .{ }^{1} \mathrm{H}$ NMR ((CD $\left.)_{2} \mathrm{CO}\right): \delta 2.66$ (s, 3H), $2.66(\mathrm{~s}, 3 \mathrm{H})$, 3.38 (bddd, $J=4.7,14.6,16.8 \mathrm{~Hz}, 1 \mathrm{H}), 3.50$ (ddd, $J=4.6,14.3,16.8 \mathrm{~Hz}, 1 \mathrm{H}), 3.84$ (ddd, $J=$ 1.9, 3.6, $16.8 \mathrm{~Hz}, 1 \mathrm{H}), 3.84(\mathrm{ddd}, J=1.9,3.6,16.8 \mathrm{~Hz}, 1 \mathrm{H}), 3.94$ (s, 3H), 5.18 (dt, $J=3.6$, $14.3,14.4 \mathrm{~Hz}, 1 \mathrm{H}), 5.20$ (dt, $J=3.6,14.2,14.2 \mathrm{~Hz}, 1 \mathrm{H}), 5.41$ (ddd, $J=1.9,4.6,14.1 \mathrm{~Hz}, 1 \mathrm{H})$, $5.74(\mathrm{ddd}, J=1.9,4.7,13.7 \mathrm{~Hz}, 1 \mathrm{H}), 7.11-7.17(\mathrm{~m}, 2 \mathrm{H}), 7.44$ (dd, $J=1.3,8.0 \mathrm{~Hz}, 1 \mathrm{H}), 7.75$ (t, $J=8.1 \mathrm{~Hz}, 1 \mathrm{H}), 7.83$ (d, $J=15.9 \mathrm{~Hz}, 1 \mathrm{H}), 7.85(\mathrm{ddd}, J=1.2,6.9,8.7 \mathrm{~Hz}, 1 \mathrm{H}), 7.88-7.91$ (m, 2H), $7.90(\mathrm{~d}, J=15.9 \mathrm{~Hz}, 1 \mathrm{H}), 8.00(\mathrm{ddd}, J=1.1,6.9,8.1 \mathrm{~Hz}, 1 \mathrm{H}), 8.11(\mathrm{dd}, J=1.3,8.2$ $\mathrm{Hz}, 1 \mathrm{H}), 8.14$ (dq, $J=0.9,8.7 \mathrm{~Hz}, 1 \mathrm{H}), 8.30$ (bddt, $J=0.7,1.2,8.1 \mathrm{~Hz}, 1 \mathrm{H}), 8.57$ (bd, $J=6.7$ $\mathrm{Hz}, 1 \mathrm{H}), 9.05(\mathrm{~d}, J=6.7 \mathrm{~Hz}, 1 \mathrm{H}) .{ }^{13} \mathrm{C} \mathrm{NMR}\left(\left(\mathrm{CD}_{3}\right)_{2} \mathrm{CO}\right): \delta 16.8,16.9,26.0,26.7,50.4,55.9$, $56.1,115.4,116.1,123.7,125.2,125.8,126.9,128.6,128.7,128.8,128.9,129.1,131.5$, $132.7,136.1,137.5,138.7,139.9,140.8,141.8,142.4,143.5,145.1,148.2,151.7,155.4$, 163.2. Elemental analysis: (\%) calcd for $\left[\mathrm{C}_{37} \mathrm{H}_{32} \mathrm{~F}_{6} \mathrm{~N}_{2} \mathrm{O}_{7} \mathrm{~S}_{2} \cdot \mathrm{H}_{2} \mathrm{O}\right] \mathrm{C}$ 54.68, H 4.22, N 3.45; found C 54.66, H 4.27, N 3.22. IR (KBr): $\tilde{v}\left(\mathrm{~cm}^{-1}\right)$ 3074, 2851, 1625, 1599, 1441, 1271, 1256, 1175, 1155, 1029. MS (ESI): $m / z(\%) 645.2\left[\left(\mathrm{M}-\mathrm{TfO}^{-}\right)^{+}\right](5), 495.2\left[\left(\mathrm{M}-2 \mathrm{TfO}^{-}\right)^{+}\right]$ (5), $248.1\left[\left(\mathrm{M}-2 \mathrm{TfO}^{-}\right)^{2+}\right](100)$. HRMS (ESI): $m / z$ calcd for $\left[\left(\mathrm{M}-\mathrm{TfO}^{-}\right)^{+}\right]\left(\mathrm{C}_{36} \mathrm{H}_{32} \mathrm{O}_{4} \mathrm{~N}_{2} \mathrm{~F}_{3} \mathrm{~S}\right)$ 645.20294; found 645.20132.

Synthesis of (E)-11-(2-(6-Methoxynaphthalen-2-yl)vinyl)-6,7-dimethyl-4,5,8,9tetrahydroisoquinolino[1,2-a]pyrido[1,2-k][2,9]phenanthroline-3,10-diium

Trifluoromethanesulfonate $\left([5][\mathbf{T f O}]_{2}\right)$. This compound was prepared and purified in a manner similar to $[\mathbf{2}][\mathrm{TfO}]_{2}$ by using $[\mathbf{I I I}][\mathrm{TfO}]_{2} \quad(75 \quad \mathrm{mg}, 0.111 \mathrm{mmol})$, 6methoxynaphthylaldehyde (144 mg, $0.776 \mathrm{mmol}, 7.1$ equiv), dry $\mathrm{MeOH}(7.5 \mathrm{~mL})$ and pyrrolidine (107 $\mu \mathrm{L}, 93 \mathrm{mg}, 1.31 \mathrm{mmol}, 11.8$ equiv). The addition of $\mathrm{Et}_{2} \mathrm{O}(60 \mathrm{~mL})$ was followed by three reprecipitations from $\mathrm{MeOH}(10 \mathrm{~mL})$ with $\mathrm{Et}_{2} \mathrm{O}(60 \mathrm{~mL})$ to give a yellow solid. Yield: $68 \mathrm{mg}(73 \%) .{ }^{1} \mathrm{H}$ NMR $\left(\mathrm{CD}_{3} \mathrm{CN}\right): \delta 2.54$ (s, 3H), 2.55 (s, 3H), 3.07 (ddd, $J=4.9$, 
14.8, 17.2 Hz, 1H), 3.18 (ddd, $J=4.5,14.8,17.2 \mathrm{~Hz}, 1 \mathrm{H}), 3.56(\mathrm{ddd}, J=1.8,3.6,17.2 \mathrm{~Hz}, 1 \mathrm{H})$, $3.60(\mathrm{ddd}, J=1.8,3.8,17.2 \mathrm{~Hz}, 1 \mathrm{H}), 3.96$ (s, 3H), 4.77 (dt, $J=3.8,14.4,14.4 \mathrm{~Hz}, 1 \mathrm{H}), 4.84$ (ddd, $J=3.6,14.3,14.3 \mathrm{~Hz}, 1 \mathrm{H}), 5.04$ (ddd, $J=1.8,4.5,13.8 \mathrm{~Hz}, 1 \mathrm{H}), 5.41$ (ddd, $J=1.8,4.9,14.0 \mathrm{~Hz}$, $1 \mathrm{H}), 6.92(\mathrm{dd}, J=1.1,8.0 \mathrm{~Hz}, 1 \mathrm{H}), 7.24(\mathrm{dd}, J=2.6,8.8 \mathrm{~Hz}, 1 \mathrm{H}), 7.35(\mathrm{~d}, J=2.6 \mathrm{~Hz}, 1 \mathrm{H}), 7.55$ (t, $J=8.1 \mathrm{~Hz}, 1 \mathrm{H}), 7.68(\mathrm{ddd}, J=1.2,6.9,8.7 \mathrm{~Hz}, 1 \mathrm{H}), 7.69$ (d, $J=15.9 \mathrm{~Hz}, 1 \mathrm{H}), 7.74(\mathrm{~d}, J=$ $15.9 \mathrm{~Hz}, 1 \mathrm{H}), 7.82$ (dq, $J=1.0,8.7 \mathrm{~Hz}, 1 \mathrm{H}), 7.84$ (dd, $J=1.1,8.2 \mathrm{~Hz}, 1 \mathrm{H}), 7.88$ (ddd, $J=1.1,6.9$, $8.1 \mathrm{~Hz}, 1 \mathrm{H}), 7.90$ (d, $J=8.8 \mathrm{~Hz}, 1 \mathrm{H}), 7.92$ (d, $J=8.6 \mathrm{~Hz}, 1 \mathrm{H}), 7.95(\mathrm{dd}, J=1.8,8.6 \mathrm{~Hz}, 1 \mathrm{H}), 8.12$ (bd, $J=8.1 \mathrm{~Hz}, 1 \mathrm{H}), 8.16(\mathrm{~d}, J=1.8 \mathrm{~Hz}, 1 \mathrm{H}), 8.30(\mathrm{bd}, J=6.7 \mathrm{~Hz}, 1 \mathrm{H}), 8.62(\mathrm{~d}, J=6.7 \mathrm{~Hz}, 1 \mathrm{H})$. ${ }^{13} \mathrm{C}$ NMR (151 MHz, $\left.\mathrm{CD}_{3} \mathrm{CN}\right): \delta 16.0,16.1,25.0,25.8,49.6,55.1,55.3,106.6,116.6,119.6$, $122.6,124.4,124.6,124.9,126.0,127.5,127.7,127.8,128.2,128.7,130.3,130.4,130.6$, $130.8,131.8,135.5,136.0,136.3,137.6,139.0,140.2,141.4,141.4,142.6,144.7,147.3$, 150.8, 154.2, 159.6. Elemental analysis: (\%) calcd for $\left[\mathrm{C}_{41} \mathrm{H}_{34} \mathrm{~F}_{6} \mathrm{~N}_{2} \mathrm{O}_{7} \mathrm{~S}_{2} \cdot \mathrm{H}_{2} \mathrm{O}\right] \mathrm{C}$ 57.07, H 4.21, N 3.25; found C 57.28, H 4.08, N 3.06. IR (KBr): $\tilde{v}\left(\mathrm{~cm}^{-1}\right) 3077,2841,1623,1608$, 1562, 1506, 1482, 1266, 1154, 1031, 638, 573, 518. MS (ESI): $m / z(\%) 695.3\left[\left(\mathrm{M}^{-} \mathrm{TfO}^{-}\right)^{+}\right]$ (15), $545.3\left[\left(\mathrm{M}-2 \mathrm{TfO}^{-}\right)^{+}\right](25), 273.1\left[\left(\mathrm{M}-2 \mathrm{TfO}^{-}\right)^{2+}\right](100)$. HRMS (ESI): $m / z$ calcd. for $\left[\left(\mathrm{M}-\mathrm{TfO}^{-}\right)^{+}\right]\left(\mathrm{C}_{40} \mathrm{H}_{34} \mathrm{O}_{4} \mathrm{~N}_{2} \mathrm{~F}_{3} \mathrm{~S}\right)$ 695.21859; found 695.21802.

Synthesis of 11-((1E,3E)-4-(4-Methoxyphenyl)buta-1,3-dienyl)-6,7-dimethyl4,5,8,9-tetrahydroisoquinolino $[1,2-a]$ pyrido $[1,2-k][2,9]$ phenanthroline-3,10-diium

Trifluoromethanesulfonate $\left([6]\left[\mathrm{TfO}_{2}\right)\right.$. This compound was prepared and purified in a manner similar to $[4][\mathrm{TfO}]_{2}$ by using $[\mathbf{I I I}][\mathrm{TfO}]_{2} \quad(100 \mathrm{mg}, \quad 0.148 \mathrm{mmol})$, 4methoxycinnamaldehyde (170 mg, $1.05 \mathrm{mmol}, 7.1$ equiv), dry $\mathrm{MeOH}(10 \mathrm{~mL})$ and pyrrolidine (143 $\mu \mathrm{L}, 124 \mathrm{mg}, 1.75 \mathrm{mmol}, 11.8$ equiv). The addition of $\mathrm{Et}_{2} \mathrm{O}(80 \mathrm{~mL})$ was followed by three reprecipitations from $\mathrm{MeOH}(5.0 \mathrm{~mL})$ with $\mathrm{Et}_{2} \mathrm{O}(40 \mathrm{~mL})$ to give an orange solid. Yield: $71 \mathrm{mg}(59 \%) .{ }^{1} \mathrm{H}$ NMR ((CD $\left.)_{2} \mathrm{CO}\right): \delta 2.66$ (s, 3H), 2.67 (s, 3H), 3.35 (bddd, $J=$ 4.8, 14.8, 17.4 Hz, 1H), 3.49 (ddd, $J=4.5,14.8,17.2 \mathrm{~Hz}, 1 \mathrm{H}), 3.82$ (ddd, $J=1.8,3.7,17.2$ $\mathrm{Hz}, 1 \mathrm{H}), 3.86(\mathrm{ddd}, J=2.0,3.7,17.4 \mathrm{~Hz}, 1 \mathrm{H}), 3.86(\mathrm{~s}, 3 \mathrm{H}), 5.07$ (dt, $J=3.7,14.5,14.5 \mathrm{~Hz}$, 1H), 5.18 (bdt, $J=3.7,14.4,14.4 \mathrm{~Hz}, 1 \mathrm{H}), 5.40$ (ddd, $J=1.8,4.5,14.0 \mathrm{~Hz}, 1 \mathrm{H}), 5.60$ (ddd, $J$ $=2.0,4.8,13.7 \mathrm{~Hz}, 1 \mathrm{H}), 6.81-6.84(\mathrm{~m}, 2 \mathrm{H}), 7.16(\mathrm{~d}, J=15.3 \mathrm{~Hz}, 1 \mathrm{H}), 7.21(\mathrm{dd}, J=10.0$, $15.3 \mathrm{~Hz}, 1 \mathrm{H}), 7.30$ (dd, $J=1.3,8.0 \mathrm{~Hz}, 1 \mathrm{H}), 7.34$ (d, $J=14.9 \mathrm{~Hz}, 1 \mathrm{H}), 7.52-7.55(\mathrm{~m}, 2 \mathrm{H})$, 
$7.66(\mathrm{t}, J=8.1 \mathrm{~Hz}, 1 \mathrm{H}), 7.75(\mathrm{dd}, J=10.0,14.9 \mathrm{~Hz}, 1 \mathrm{H}), 7.81(\mathrm{ddd}, J=1.2,6.9,8.8 \mathrm{~Hz}, 1 \mathrm{H})$, $8.01(\mathrm{ddd}, J=1.1,6.9,8.1 \mathrm{~Hz}, 1 \mathrm{H}), 8.04(\mathrm{dd}, J=1.3,8.2 \mathrm{~Hz}, 1 \mathrm{H}), 8.14$ (dq, $J=0.9,8.8 \mathrm{~Hz}$, $1 \mathrm{H}), 8.29$ (bd, $J=8.1 \mathrm{~Hz}, 1 \mathrm{H}), 8.55(\mathrm{bd}, J=6.7 \mathrm{~Hz}, 1 \mathrm{H}), 9.03(\mathrm{~d}, J=6.7 \mathrm{~Hz}, 1 \mathrm{H}) .{ }^{13} \mathrm{C} \mathrm{NMR}$ $\left(\left(\mathrm{CD}_{3}\right)_{2} \mathrm{CO}\right): \delta 16.8,16.9,26.0,26.8,50.1,55.8,56.2,115.4,120.1,123.7,124.8,125.7$, $126.4,126.9,128.7,128.7,129.0,129.1,129.7,130.1,132.6,136.1,137.5,138.6,139.9$, 140.7, 141.8, 142.4 143.0, 143.2, 146.4, 148.1, 151.7, 154.8, 162.1. Elemental analysis: calcd for $\left[\mathrm{C}_{39} \mathrm{H}_{34} \mathrm{~F}_{6} \mathrm{~N}_{2} \mathrm{O}_{7} \mathrm{~S}_{2}\right] \mathrm{C} 57.07, \mathrm{H} 4.18, \mathrm{~N} 3.41$; found $\mathrm{C} 56.72, \mathrm{H} 4.14, \mathrm{~N} 3.13$. IR (KBr): $\tilde{v}$ $\left(\mathrm{cm}^{-1}\right) 3074,2483,1626,1589,1577,1485,1259,1155,1030,638,573,517$. MS (ESI): $m / z$ $(\%) 671.2\left[\left(\mathrm{M}-\mathrm{TfO}^{-}\right)^{+}\right](12), 521.2\left[\left(\mathrm{M}-2 \mathrm{TfO}^{-}\right)^{+}\right](13), 261.1\left[\left(\mathrm{M}-2 \mathrm{TfO}^{-}\right)^{2+}\right](100)$. HRMS (ESI): $m / z$ calcd for $\left[\left(\mathrm{M}-\mathrm{TfO}^{-}\right)^{+}\right]\left(\mathrm{C}_{38} \mathrm{H}_{34} \mathrm{O}_{4} \mathrm{~N}_{2} \mathrm{~F}_{3} \mathrm{~S}\right)$ 671.21859; found 671.21833. Crystals suitable for X-ray diffraction analysis were grown by slow diffusion of $\left({ }^{i} \mathrm{Pr}\right)_{2} \mathrm{O}$ vapor into a $\mathrm{MeOH}$ solution at room temperature in the dark over 8-10 d.

Synthesis of $\quad(E)-13-(4-M e t h o x y s t y r y l)-6,7-d i m e t h y l-4,5,8,9-$ tetrahydroisoquinolino[1,2-a]pyrido[1,2-k][2,9]phenanthroline-3,10-diium

Trifluoromethanesulfonate $\left([7][\mathbf{T f O}]_{2}\right)$. This compound was prepared and purified in a manner similar to $[4][\mathrm{TfO}]_{2}$ by using $[\mathbf{I I}][\mathrm{TfO}]_{2} \quad(80 \quad \mathrm{mg}, \quad 0.118 \mathrm{mmol})$, 4methoxybenzaldehyde (29 $\mu \mathrm{L}, 33 \mathrm{mg}, 0.239 \mathrm{mmol}, 2$ equiv), dry $\mathrm{MeOH}(1.4 \mathrm{~mL})$ and pyrrolidine (69 $\mu \mathrm{L}, 60 \mathrm{mg}, 0.841 \mathrm{mmol}, 7.1$ equiv). The addition of $\mathrm{Et}_{2} \mathrm{O}(90 \mathrm{~mL})$ was followed by three reprecipitations from $\mathrm{MeOH}(1.0 \mathrm{~mL})$ with $\mathrm{Et}_{2} \mathrm{O}(15 \mathrm{~mL})$ to give a yellow solid. Yield $79 \mathrm{mg}(84 \%) .{ }^{1} \mathrm{H}$ NMR $\left(\left(\mathrm{CD}_{3}\right)_{2} \mathrm{CO}\right): \delta 2.64$ (s, 3H), 2.65 (s, 3H), 3.39 (bddd, $J=$ 5.2, 14.5, $17.0 \mathrm{~Hz}, 1 \mathrm{H}), 3.47$ (bdt, $J=4.6,15.8,15.8 \mathrm{~Hz}, 1 \mathrm{H}), 3.81$ (ddd, $J=1.9,3.6,17.0$ $\mathrm{Hz}, 1 \mathrm{H}), 3.81(\mathrm{ddd}, J=1.9,3.7,17.0 \mathrm{~Hz}, 1 \mathrm{H}), 3.89$ (s, 3H), 5.21 (dt, $J=3.6,14.0,14.0 \mathrm{~Hz}$, $1 \mathrm{H}), 5.24(\mathrm{dt}, J=3.6,14.0,14.0 \mathrm{~Hz}, 1 \mathrm{H}), 5.27(\mathrm{ddd}, J=1.9,5.2,13.7 \mathrm{~Hz}, 1 \mathrm{H}), 5.38$ (ddd, $J=$ 1.9, 4.6, 14.1 Hz, 1H), $6.80(\mathrm{~d}, J=16.3 \mathrm{~Hz}, 1 \mathrm{H}), 6.96-6.98(\mathrm{~m}, 2 \mathrm{H}), 7.28(\mathrm{~d}, J=16.3 \mathrm{~Hz}$, $1 \mathrm{H}), 7.40(\mathrm{~d}, J=2.0 \mathrm{~Hz}, 1 \mathrm{H}), 7.55-7.57(\mathrm{~m}, 2 \mathrm{H}), 7.79(\mathrm{ddd}, J=1.3,6.9,8.7 \mathrm{~Hz}, 1 \mathrm{H}), 7.89$ $(\mathrm{dd}, J=2.0,6.6 \mathrm{~Hz}, 1 \mathrm{H}), 7.96(\mathrm{ddd}, J=1.1,6.9,8.1 \mathrm{~Hz}, 1 \mathrm{H}), 8.13(\mathrm{dq}, J=0.9,0.9,0.9,8.7$ $\mathrm{Hz}, 1 \mathrm{H}), 8.21$ (bdt, $J=0.7,0.7,1.3,8.1 \mathrm{~Hz}, 1 \mathrm{H}), 8.57$ (bd, $J=6.7 \mathrm{~Hz}, 1 \mathrm{H}), 8.92$ (d, $J=6.6$ $\mathrm{Hz}, 1 \mathrm{H}), 9.08(\mathrm{~d}, J=6.7 \mathrm{~Hz}, 1 \mathrm{H}) .{ }^{13} \mathrm{C} \mathrm{NMR}\left(\left(\mathrm{CD}_{3}\right)_{2} \mathrm{CO}\right): \delta 16.95,17.01,26.3,26.7,54.5$, $55.9,56.3,100.9,115.3,120.6,120.9,123.3,123.6,125.3,126.8,126.9,128.2,128.6,128.9$, 
$131.2,132.6,136.2,138.0,138.9,139.8,141.1,142.0,142.4,145.5,147.5,151.8,154.4$, 162.9. Elemental analysis: (\%) calcd for $\left[\mathrm{C}_{37} \mathrm{H}_{32} \mathrm{~F}_{6} \mathrm{~N}_{2} \mathrm{O}_{7} \mathrm{~S}_{2}\right] \mathrm{C} 55.91, \mathrm{H} 4.06, \mathrm{~N} 4.79$; found $\mathrm{C}$ 55.93, H 4.21, N 4.62. IR (KBr): $\tilde{v}\left(\mathrm{~cm}^{-1}\right)$ 2841, 1627, 1618, 1552, 1514, 1445, 1433, 1411, 1379, 1356, 1156, 1030, 1020, 836, 755, 679, 638, 573, 518. MS (ESI): $m / z(\%) 645.2$ [(M $\left.\left.\mathrm{TfO}^{-}\right)^{+}\right](45), 496.3\left[\left(\mathrm{M}-2 \mathrm{TfO}^{-}\right)^{+}\right](43), 248.1\left[\left(\mathrm{M}-2 \mathrm{TfO}^{-}\right)^{2+}\right](41)$. HRMS (ESI): $m / z$ calcd for $\left[\left(\mathrm{M}-\mathrm{TfO}^{-}\right)^{+}\right]\left(\mathrm{C}_{36} \mathrm{H}_{32} \mathrm{~N}_{2} \mathrm{~F}_{3} \mathrm{~S}\right)$ 645.20294; found 645.20339.

Synthesis of (E)-13-(2-(6-Methoxynaphthalen-2-yl)vinyl)-6,7-dimethyl-4,5,8,9tetrahydro-isoquinolino[1,2-a]pyrido[1,2-k][2,9]phenanthroline-3,10-diium

Trifluoromethanesulfonate $\left([8][\mathbf{T f O}]_{2}\right)$. This compound was prepared and purified in a manner similar to $[4][\mathrm{TfO}]_{2}$ by using $[\mathbf{I I}][\mathrm{TfO}]_{2}$ (300 $\left.\mathrm{mg}, 0.443 \mathrm{mmol}\right)$, 6-methoxy-2naphthaldehyde (413 mg, $2.22 \mathrm{mmol}, 5.0$ equiv), dry $\mathrm{MeOH}(6.0 \mathrm{~mL})$ and pyrrolidine (185 $\mu \mathrm{L}, 160 \mathrm{mg}, 2.25 \mathrm{mmol}, 5.1$ equiv). The addition of $\mathrm{Et}_{2} \mathrm{O}(160 \mathrm{~mL})$ was followed by three reprecipitations from $\mathrm{MeOH}(10 \mathrm{~mL})$ with $\mathrm{Et}_{2} \mathrm{O}(140 \mathrm{~mL})$ to give an orange solid. Yield 281 $\operatorname{mg}(75 \%) .{ }^{1} \mathrm{H}$ NMR $\left(\mathrm{CD}_{3} \mathrm{CN}\right): \delta 2.44(\mathrm{~s}, 3 \mathrm{H}), 2.45$ (s, 3H), $3.05(\mathrm{ddd}, J=5.0,14.2,17.1 \mathrm{~Hz}$, 1H), 3.15 (bdt, $J=4.6,15.5,15.5 \mathrm{~Hz}, 1 \mathrm{H}), 3.50$ (ddd, $J=1.9,3.5,16.8 \mathrm{~Hz}, 1 \mathrm{H}), 3.53$ (ddd, $J$ $=1.8,3.8,17.1 \mathrm{~Hz}, 1 \mathrm{H}), 3.93(\mathrm{~s}, 3 \mathrm{H}), 4.80(\mathrm{ddd}, J=3.8,13.6,14.2 \mathrm{~Hz}, 1 \mathrm{H}), 4.88(\mathrm{ddd}, J=$ 1.8, 5.0, $13.6 \mathrm{~Hz}, 1 \mathrm{H}), 4.93(\mathrm{ddd}, J=3.5,14.0,14.7 \mathrm{~Hz}, 1 \mathrm{H}), 5.07$ (ddd, $J=1.9,4.6,14.0 \mathrm{~Hz}$, 1H), $6.73(\mathrm{~d}, J=16.3 \mathrm{~Hz}, 1 \mathrm{H}), 6.94(\mathrm{~d}, J=2.0 \mathrm{~Hz}, 1 \mathrm{H}), 7.07$ (d, $J=16.3 \mathrm{~Hz}, 1 \mathrm{H}), 7.22$ (dd, $J$ $=2.6,8.8 \mathrm{~Hz}, 1 \mathrm{H}), 7.29(\mathrm{~d}, J=2.6 \mathrm{~Hz}, 1 \mathrm{H}), 7.54(\mathrm{dd}, J=1.8,8.6 \mathrm{~Hz}, 1 \mathrm{H}), 7.57(\mathrm{dd}, J=2.0$, $6.6 \mathrm{~Hz}, 1 \mathrm{H}), 7.60(\mathrm{ddd}, J=1.2,6.9,8.8 \mathrm{~Hz}, 1 \mathrm{H}), 7.74(\mathrm{bd}, J=8.6 \mathrm{~Hz}, 1 \mathrm{H}), 7.75(\mathrm{dq}, J=0.9$, $0.9,0.9,8.8 \mathrm{~Hz}, 1 \mathrm{H}), 7.82$ (ddd, $J=1.1,6.9,8.2 \mathrm{~Hz}, 1 \mathrm{H}), 7.83(\mathrm{~d}, J=1.8 \mathrm{~Hz}, 1 \mathrm{H}), 7.84$ (d, $J$ $=8.8 \mathrm{~Hz}, 1 \mathrm{H}), 7.99(\mathrm{ddt}, J=0.7,0.7,1.2,8.2 \mathrm{~Hz}, 1 \mathrm{H}), 8.31(\mathrm{dd}, J=0.6,6.7 \mathrm{~Hz}, 1 \mathrm{H}), 8.49$ (d, $J=6.6 \mathrm{~Hz}, 1 \mathrm{H}), 8.71(\mathrm{~d}, J=6.7 \mathrm{~Hz}, 1 \mathrm{H}) .{ }^{13} \mathrm{C} \mathrm{NMR}\left(\mathrm{CD}_{3} \mathrm{CN}\right): \delta 17.1,17.2,26.1,26.7,54.6$, $56.2,56.3,107.3,120.6,121.4,121.9,123.3,125.0,125.5,126.6,126.9,127.8,128.6,128.7$, $129.0,129.5,131.1,131.1,131.3,132.8,136.5,137.0,137.5,138.6,139.8,141.4,142.3$, 142.3, 142.7, 145.5, 147.3, 151.8, 153.9, 160.3. Elemental analysis: (\%) calcd for $\left[\mathrm{C}_{41} \mathrm{H}_{34} \mathrm{~F}_{6} \mathrm{~N}_{2} \mathrm{O}_{7} \mathrm{~S}_{2}\right] \mathrm{C} 58.29, \mathrm{H} 4.06, \mathrm{~N} 3.32$; found $\mathrm{C} 58.22, \mathrm{H} 3.88, \mathrm{~N}$ 3.16. IR: $\tilde{v}\left(\mathrm{~cm}^{-1}\right)$ 2843, 1629, 1602, 1573, 1552, 1508, 1484, 1439, 1411, 1393, 1381, 1352, 1265, 1224, 1164, 1117, 1030, 980, 818, 679, 638, 573, 518. MS (ESI): $m / z(\%) 695.2\left[\left(\mathrm{M}-\mathrm{TfO}^{-}\right)^{+}\right](8), 546.3$ 
$\left[\left(\mathrm{M}-2 \mathrm{TfO}^{-}\right)^{+}\right](25), 273.1\left[\left(\mathrm{M}-2 \mathrm{TfO}^{-}\right)^{2+}\right]$. HRMS $(\mathrm{ESI}): m / z$ calcd for $\left[\left(\mathrm{M}-\mathrm{TfO}^{-}\right)^{+}\right]$ $\left(\mathrm{C}_{40} \mathrm{H}_{34} \mathrm{~F}_{3} \mathrm{~N}_{2} \mathrm{O}_{4} \mathrm{~S}\right)$ 695.21859; found: 695.21812.

Synthesis of 13-((1E,3E)-4-(4-Methoxyphenyl)buta-1,3-dien-1-yl)-6,7-dimethyl4,5,8,9-tetrahydroisoquinolino $[1,2-a]$ pyrido $[1,2-k][2,9]$ phenanthroline-3,10-diium

Trifluoromethanesulfonate $\left([9][\mathbf{T f O}]_{2}\right)$. This compound was prepared and purified in a manner similar to $[4][\mathrm{TfO}]_{2}$ by using $[\mathbf{I I}][\mathrm{TfO}]_{2} \quad(100 \mathrm{mg}, \quad 0.148 \mathrm{mmol}), \quad p$ methoxycinnamaldehyde (72 $\mathrm{mg}, 0.441 \mathrm{mmol}, 3.0$ equiv), dry $\mathrm{MeOH}(1.7 \mathrm{~mL})$ and pyrrolidine (139 $\mu \mathrm{L}, 120 \mathrm{mg}, 1.69 \mathrm{mmol}, 11.4$ equiv). The reaction time was $1 \mathrm{~h}$. The addition of $\mathrm{Et}_{2} \mathrm{O}(90 \mathrm{~mL})$ was followed by three reprecipitations from $\mathrm{MeOH}(6.0 \mathrm{~mL})$ with $\mathrm{Et}_{2} \mathrm{O}(64 \mathrm{~mL})$ to give an orange solid. Yield $40 \mathrm{mg}(33 \%) .{ }^{1} \mathrm{H}$ NMR $\left(\left(\mathrm{CD}_{3}\right)_{2} \mathrm{CO}\right): \delta 2.64(\mathrm{~s}$, 3H), 2.64 (s, 3H), 3.40 (bddd, $J=5.6,14.4,17.0 \mathrm{~Hz}, 1 \mathrm{H}$ ), 3.48 (bddd, $J=4.6,13.2,17.0 \mathrm{~Hz}$, $1 \mathrm{H}), 3.80(\mathrm{ddd}, J=1.8,3.6,17.0 \mathrm{~Hz}, 1 \mathrm{H}), 3.82(\mathrm{ddd}, J=1.9,3.7,17.0 \mathrm{~Hz}, 1 \mathrm{H}), 3.88(\mathrm{~s}, 3 \mathrm{H})$, $5.20(\mathrm{dt}, J=3.6,13.6,13.6 \mathrm{~Hz}, 1 \mathrm{H}), 5.22(\mathrm{dt}, 3.7,14.0,14.0 \mathrm{~Hz}, 1 \mathrm{H}), 5.26(\mathrm{ddd}, J=1.9,5.6$, $13.6 \mathrm{~Hz}, 1 \mathrm{H}), 5.40(\mathrm{ddd}, J=1.8,4.6,14.0 \mathrm{~Hz}, 1 \mathrm{H}), 6.34$ (d, $J=14.5 \mathrm{~Hz}, 1 \mathrm{H}), 6.83$ (ddd, $J=$ $0.8,10.7,15.4 \mathrm{~Hz}, 1 \mathrm{H}), 6.96(\mathrm{~d}, J=15.4 \mathrm{~Hz}, 1 \mathrm{H}), 6.98-7.01(\mathrm{~m}, 2 \mathrm{H}), 7.12$ (ddd, $J=0.7$, 10.7, 15.4 Hz, 1H), $7.30(\mathrm{~d}, J=2.0 \mathrm{~Hz}, 1 \mathrm{H}), 7.51-7.54(\mathrm{~m}, 2 \mathrm{H}), 7.79(\mathrm{dd}, J=2.0,6.6 \mathrm{~Hz}$, 1H), 7.81 (ddd, $J=1.2,6.9,8.8 \mathrm{~Hz}, 1 \mathrm{H}), 8.00$ (ddd, $J=1.0,6.9,8.1 \mathrm{~Hz}, 1 \mathrm{H}), 8.15$ (dq, $J=$ $0.9,8.8 \mathrm{~Hz}, 1 \mathrm{H}), 8.27$ (ddt, $J=0.7,1.2,8.1 \mathrm{~Hz}, 1 \mathrm{H}), 8.61$ (bd, $J=6.7 \mathrm{~Hz}, 1 \mathrm{H}), 8.90$ (d, $J=$ $6.6 \mathrm{~Hz}, 1 \mathrm{H}), 9.12(\mathrm{~d}, J=6.7 \mathrm{~Hz}, 1 \mathrm{H}) .{ }^{13} \mathrm{C} \mathrm{NMR}\left(\left(\mathrm{CD}_{3}\right)_{2} \mathrm{CO}\right): \delta 16.9,17.0,26.3,26.6,54.4$, $55.7,56.3,115.2,121.0,123.6,125.2,125.3,126.1,126.4,126.9,128.2,128.9,129.0,129.8$, $129.9,132.6,136.2,137.9,138.8,139.8,141.0,142.2,142.3,142.3,143.4,145.5,147.3$, 151.8, 153.9, 161.9. Elemental analysis: (\%) calcd for $\left[\mathrm{C}_{39} \mathrm{H}_{34} \mathrm{~F}_{6} \mathrm{~N}_{2} \mathrm{O}_{7} \mathrm{~S}_{2}\right] \mathrm{C} 57.07, \mathrm{H} 4.18, \mathrm{~N}$ 3.41; found C 56.67, H 4.15, N 3.16. IR (KBr): $\tilde{v}\left(\mathrm{~cm}^{-1}\right)$ 1627, 1610, 1595, 1573, 1512, 1434 , 1413, 1357, 1273, 1260, 1224, 1173, 1154, 1115, 1030, 826, 756, 638, 573, 518. MS (ESI): $m / z(\%) 671.3\left[\left(\mathrm{M}-\mathrm{TfO}^{-}\right)^{+}\right](78), 522.3(43)\left[\left(\mathrm{M}-2 \mathrm{TfO}^{-}\right)^{+}\right], 261.1\left[\left(\mathrm{M}-2 \mathrm{TfO}^{-}\right)^{2+}\right](100)$. HRMS (ESI): $m / z$ calcd for $\left[\left(\mathrm{M}-\mathrm{TfO}^{-}\right)^{+}\right]\left(\mathrm{C}_{38} \mathrm{H}_{34} \mathrm{O}_{4} \mathrm{~N}_{2} \mathrm{~F}_{3} \mathrm{~S}\right)$ calc.: 671.21859; found 671.21886 .

Synthesis of $\quad(E)-13-(4-(D i m e t h y l a m i n o) s t y r y l)-6,7-d i m e t h y l-4,5,8,9-$ tetrahydroisoquinolino[1,2-a]pyrido[1,2-k][2,9]phenanthroline-3,10-diium 
Trifluoromethanesulfonate $\left([\mathbf{1 0}][\mathbf{T f O}]_{2}\right)$. This compound was prepared and purified in a manner similar to $[4][\mathrm{TfO}]_{2}$ by using $[\mathbf{I I}][\mathrm{TfO}]_{2} \quad(300 \quad \mathrm{mg}, \quad 0.443 \mathrm{mmol})$, 4dimethylaminobenzaldehyde (330 mg, $2.21 \mathrm{mmol}, 5.0$ equiv), dry $\mathrm{MeOH}(6.0 \mathrm{~mL})$ and pyrrolidine (185 $\mu \mathrm{L}, 160 \mathrm{mg}, 2.25 \mathrm{mmol}, 5.1$ equiv). The addition of $\mathrm{Et}_{2} \mathrm{O}(90 \mathrm{~mL})$ was followed by three reprecipitations from $\mathrm{MeOH}(6.0 \mathrm{~mL})$ with $\mathrm{Et}_{2} \mathrm{O}(170 \mathrm{~mL})$ to give a red solid. Yield: $251 \mathrm{mg}(70 \%) .{ }^{1} \mathrm{H}$ NMR ((CD $\left.)_{2} \mathrm{CO}\right): \delta 2.62$ (s, 3H), 2.63 (s, 3H), $3.10(\mathrm{~s}, 6 \mathrm{H})$, $3.36(\mathrm{ddd}, J=5.2,14.4,16.9 \mathrm{~Hz}, 1 \mathrm{H}), 3.45$ (bdt, $J=3.5,16.0,16.6 \mathrm{~Hz}, 1 \mathrm{H}), 3.78$ (ddd, $J=$ $1.9,3.6,16.9 \mathrm{~Hz}, 1 \mathrm{H}), 3.78(\mathrm{ddd}, J=1.9,3.5,16.9 \mathrm{~Hz}, 1 \mathrm{H}), 5.14(\mathrm{dt}, J=3.5,14.0,14.0 \mathrm{~Hz}$, 1H), $5.20(\mathrm{ddd}, J=1.9,5.2,13.5 \mathrm{~Hz}, 1 \mathrm{H}), 5.22$ (bdt, $J=3.5,14.7,14.7 \mathrm{~Hz}, 1 \mathrm{H}), 5.38$ (ddd, $J$ $=1.9,3.6,14.0 \mathrm{~Hz}, 1 \mathrm{H}), 6.59(\mathrm{~d}, J=16.0 \mathrm{~Hz}, 1 \mathrm{H}), 6.74-6.76(\mathrm{~m}, 2 \mathrm{H}), 7.19(\mathrm{~d}, J=16.0 \mathrm{~Hz}$, 1H), $7.25(\mathrm{~d}, J=2.0 \mathrm{~Hz}, 1 \mathrm{H}), 7.42-7.45(\mathrm{~m}, 2 \mathrm{H}), 7.74(\mathrm{dd}, 2.0,6.7 \mathrm{~Hz}, 1 \mathrm{H}), 7.79$ (ddd, $J=$ $1.3,6.9,8.7 \mathrm{~Hz}, 1 \mathrm{H}), 7.96(\mathrm{ddd}, J=1.1,6.9,8.1 \mathrm{~Hz}, 1 \mathrm{H}), 8.12(\mathrm{dq}, J=1.0,1.0,1.0,8.7 \mathrm{~Hz}$, 1H), 8.20 (bdt, 0.7, 0.7, 1.3, 8.1 Hz, 1H), 8.55 (bd, $J=6.7 \mathrm{~Hz}, 1 \mathrm{H}), 8.77$ (d, $J=6.7 \mathrm{~Hz}, 1 \mathrm{H})$, $9.09(\mathrm{~d}, J=6.7 \mathrm{~Hz}, 1 \mathrm{H}) .{ }^{13} \mathrm{C} \mathrm{NMR}\left(\left(\mathrm{CD}_{3}\right)_{2} \mathrm{CO}\right): \delta 17.0,17.1,26.4,26.7,40.1,54.0,56.3$, $112.7,117.1,120.0,123.5,123.5,125.3,126.0,126.9,128.4,128.9,129.0,131.4,132.6$, $136.2,137.8,138.7,139.8,140.8,142.2,142.3,143.3,144.9,146.8,152.0,153.4,154.8$. Elemental analysis: (\%) calcd for $\left[\mathrm{C}_{38} \mathrm{H}_{35} \mathrm{~F}_{6} \mathrm{~N}_{3} \mathrm{O}_{6} \mathrm{~S}_{2}\right] \mathrm{C} 56.50, \mathrm{H} 4.37$, N 5.20; found C 56.35, H 4.20, N 5.09. IR (KBr): $\tilde{v}\left(\mathrm{~cm}^{-1}\right)$ 2807, 1630, 1576, 1550, 1508, 1434, 1428, 1412, 1371, $1275,1260,1224,1187,1162,1110,1030,944,889,819,755,678,637,573,517$. MS (ESI): $m / z(\%) 658.5\left[\left(\mathrm{M}-\mathrm{TfO}^{-}\right)^{+}\right](5), 509.5\left[\left(\mathrm{M}-2 \mathrm{TfO}^{-}\right)^{+}\right](18), 254.7\left[\left(\mathrm{M}-2 \mathrm{TfO}^{-}\right)^{2+}\right](100)$. HRMS (ESI): $m / z(\%)$ calcd for $\left[\left(\mathrm{M}-\mathrm{TfO}^{-}\right)^{+}\right]\left(\mathrm{C}_{37} \mathrm{H}_{35} \mathrm{~N}_{3} \mathrm{~F}_{3} \mathrm{~S}\right)$ 658.23457; found 658.23429.

Synthesis of $(E)-13-(2-(1,2,3,5,6,7-H e x a h y d r o p y r i d o[3,2,1-i j] q u i n o l i n-9-y l) v i n y l)-$ 6,7-dimethyl-4,5,8,9-tetrahydroisoquinolino[1,2-a]pyrido[1,2-k][2,9]phenanthroline-

3,10-diium Trifluoromethanesulfonate $\left([11]\left[\mathrm{TfO}_{2}\right)\right.$. This compound was prepared and purified in a manner similar to $[4][\mathrm{TfO}]_{2}$ by using $[\mathbf{I I}][\mathrm{TfO}]_{2}(260 \mathrm{mg}, 0.384 \mathrm{mmol})$, 9julolidinecarboxaldehyde (387 mg, $1.92 \mathrm{mmol}, 5.0$ equiv), dry $\mathrm{MeOH}(8 \mathrm{~mL})$ and pyrrolidine (160 $\mu \mathrm{L}, 139 \mathrm{mg}, 1.95 \mathrm{mmol}, 5.1$ equiv). The reaction time was $4 \mathrm{~h}$. The addition of $\mathrm{Et}_{2} \mathrm{O}$ $(240 \mathrm{~mL})$ was followed by three reprecipitations from $\mathrm{MeOH}(5.0 \mathrm{~mL})$ with $\mathrm{Et}_{2} \mathrm{O}(150 \mathrm{~mL})$ to give a blue solid. Yield: $320 \mathrm{mg}(97 \%) .{ }^{1} \mathrm{H}$ NMR (600 MHz, $\left.\mathrm{CD}_{3} \mathrm{CN}\right): \delta 1.93-1.98(\mathrm{~m}, 4 \mathrm{H})$, 
$2.61(\mathrm{~s}, 3 \mathrm{H}), 2.63(\mathrm{~s}, 3 \mathrm{H}), 2.70-2.76(\mathrm{~m}, 4 \mathrm{H}), 3.33-3.36(\mathrm{~m}, 4 \mathrm{H}), 3.35$ (bdt, $J=5.1,14.5$, $16.8 \mathrm{~Hz}, 1 \mathrm{H}), 3.44$ (bdt, $J=4.8,15.9,15.9 \mathrm{~Hz}, 1 \mathrm{H}), 3.75$ (ddd, $J=2.0,3.6,16.8 \mathrm{~Hz}, 1 \mathrm{H})$, $3.75(\mathrm{ddd}, J=1.9,3.8,16.8 \mathrm{~Hz}, 1 \mathrm{H}), 5.09$ (dt, $J=3.6,14.0,14.0 \mathrm{~Hz}, 1 \mathrm{H}), 5.16(\mathrm{ddd}, J=2.0$, 5.1, $13.5 \mathrm{~Hz}, 1 \mathrm{H}), 5.23$ (dt, $J=3.8,14.8,14.8 \mathrm{~Hz}, 1 \mathrm{H}), 5.36$ (ddd, $J=1.9,4.8,14.0 \mathrm{~Hz}, 1 \mathrm{H})$, $6.50(\mathrm{~d}, J=15.9 \mathrm{~Hz}, 1 \mathrm{H}), 7.00(\mathrm{~s}, 2 \mathrm{H}), 7.11(\mathrm{~d}, J=15.9 \mathrm{~Hz}, 1 \mathrm{H}), 7.18(\mathrm{~d}, J=2.0 \mathrm{~Hz}, 1 \mathrm{H})$, $7.65(\mathrm{dd}, J=2.0,6.8 \mathrm{~Hz}, 1 \mathrm{H}), 7.80(\mathrm{ddd}, J=1.3,6.9,8.1 \mathrm{~Hz}, 1 \mathrm{H}), 7.97(\mathrm{ddd}, J=1.1,6.9,8.1$ $\mathrm{Hz}, 1 \mathrm{H}), 8.13$ (dq, $J=0.9,0.9,0.9,8.7 \mathrm{~Hz}, 1 \mathrm{H}), 8.21$ (bddt, $J=0.7,0.7,1.3,8.1 \mathrm{~Hz}, 1 \mathrm{H}$ ), $8.54(\mathrm{bd}, J=6.7 \mathrm{~Hz}, 1 \mathrm{H}), 8.70(\mathrm{~d}, J=6.8 \mathrm{~Hz}, 1 \mathrm{H}), 9.08(\mathrm{~d}, J=6.7 \mathrm{~Hz}, 1 \mathrm{H}) .{ }^{13} \mathrm{C} \mathrm{NMR}$ $\left(\mathrm{CD}_{3} \mathrm{CN}\right): \delta 16.93,16.96,22.1,26.5,26.7,28.2,50.6,53.8,56.3,115.7,119.3,122.6,123.9$, 125.2 , 125.6, 126.9, 128.6, 128.9, 129.0, 129.3, 132.0, 132.5, 136.1, 137.8, 138.6, 139.7, 140.6, 142.1, 142.2, 143.8, 144.4, 146.6, 146.7, 152.0, 154.9. Elemental analysis: (\%) calcd for $\left[\mathrm{C}_{42} \mathrm{H}_{39} \mathrm{~F}_{6} \mathrm{~N}_{3} \mathrm{O}_{6} \mathrm{~S}_{2} \cdot \mathrm{H}_{2} \mathrm{O}\right] \mathrm{C} 57.46, \mathrm{H} 4.71, \mathrm{~N}$ 4.79; found C 57.39, H 4.62, N 4.39. IR (KBr): $\tilde{v}\left(\mathrm{~cm}^{-1}\right) 2935,2842,1631,1573,1562,1522,1508,1378,1355,1316,1275,1260,1221$, 1208, 1157, 1108, 1084, 1052, 1030, 819, 754, 730, 679, 637, 573, 517. MS (ESI): $m / z(\%)$

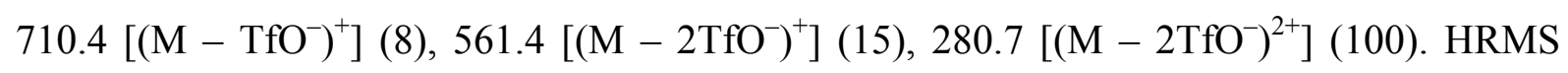
(ESI): $m / z(\%)$ calcd for $\left[\left(\mathrm{M}-\mathrm{TfO}^{-}\right)^{+}\right]\left(\mathrm{C}_{41} \mathrm{H}_{39} \mathrm{~F}_{3} \mathrm{~N}_{3} \mathrm{O}_{3} \mathrm{~S}\right) 710.26587$; found 710.26598.

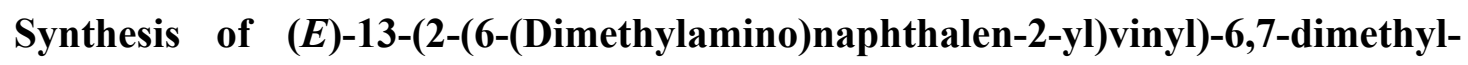
4,5,8,9-tetrahydroisoquinolino $[1,2-a]$ pyrido $[1,2-k][2,9]$ phenanthroline-3,10-diium

Trifluoromethanesulfonate $\left([\mathbf{1 2}]\left[\mathrm{TfO}_{2}\right)\right.$. This compound was prepared and purified in a manner similar to $[\mathbf{1 1}][\mathrm{TfO}]_{2}$ by using $[\mathbf{I I}][\mathrm{TfO}]_{2}(58 \mathrm{mg}, 0.085 \mathrm{mmol})$, 6-dimethylamino-2naphthaldehyde $(22 \mathrm{mg}, 0.110 \mathrm{mmol}, 1.3$ equiv), dry $\mathrm{MeOH}(1.0 \mathrm{~mL})$ and pyrrolidine $(80 \mu \mathrm{L}$, $69 \mathrm{mg}, 0.974 \mathrm{mmol}, 11.5$ equiv). The addition of $\mathrm{Et}_{2} \mathrm{O}(15 \mathrm{~mL})$ was followed by three reprecipitations from $\mathrm{MeOH}(0.5 \mathrm{~mL})$ with $\mathrm{Et}_{2} \mathrm{O}(10 \mathrm{~mL})$ to give a red solid. Yield: $49 \mathrm{mg}$ (67\%). ${ }^{1} \mathrm{H}$ NMR $\left(\left(\mathrm{CD}_{3}\right)_{2} \mathrm{CO}\right): \delta 2.52(\mathrm{~s}, 3 \mathrm{H}), 2.53(\mathrm{~s}, 3 \mathrm{H}), 3.18(\mathrm{~s}, 6 \mathrm{H}), 3.32$ (bddd, $J=5.2$, 14.5, 17.0 Hz, 1H), 3.44 (bdt, $J=4.6,16.0,16.0 \mathrm{~Hz}, 1 \mathrm{H}$ ), 3.75 (ddd, $J=1.9,3.6,17.0 \mathrm{~Hz}$, 1H), 3.75 (ddd, $J=1.9,3.8,17.0 \mathrm{~Hz}, 1 \mathrm{H}), 5.16(\mathrm{dt}, J=3.8,14.0,14.0 \mathrm{~Hz}, 1 \mathrm{H}), 5.24$ (ddd, $J=$ $1.9,5.2,13.6 \mathrm{~Hz}, 1 \mathrm{H}), 5.26(\mathrm{dt}, J=3.6,14.8,14.8 \mathrm{~Hz}, 1 \mathrm{H}), 5.41$ (ddd, $J=1.9,4.6,13.8 \mathrm{~Hz}$, $1 \mathrm{H}), 6.85(\mathrm{~d}, J=16.0 \mathrm{~Hz}, 1 \mathrm{H}), 7.03(\mathrm{~d}, J=2.6 \mathrm{~Hz}, 1 \mathrm{H}), 7.31(\mathrm{dd}, J=2.6,9.0 \mathrm{~Hz}, 1 \mathrm{H}), 7.33$ $(\mathrm{d}, J=16.0 \mathrm{~Hz}, 1 \mathrm{H}), 7.35(\mathrm{~d}, J=2.0 \mathrm{~Hz}, 1 \mathrm{H}), 7.53(\mathrm{dd}, J=1.8,8.6 \mathrm{~Hz}, 1 \mathrm{H}), 7.63(\mathrm{~d}, J=8.6$ 
$\mathrm{Hz}, 1 \mathrm{H}), 7.76(\mathrm{ddd}, J=1.2,6.9,8.7 \mathrm{~Hz}, 1 \mathrm{H}), 7.81(\mathrm{bd}, J=9.0 \mathrm{~Hz}, 1 \mathrm{H}), 7.86(\mathrm{dd}, J=2.0,6.7$ $\mathrm{Hz}, 1 \mathrm{H}), 7.86(\mathrm{~d}, J=1.8 \mathrm{~Hz}, 1 \mathrm{H}), 7.94(\mathrm{ddd}, J=1.0,6.9,8.1 \mathrm{~Hz}, 1 \mathrm{H}), 8.08$ (dq, $J=0.9,0.9$, 0.9, $8.7 \mathrm{~Hz}, 1 \mathrm{H}), 8.17$ (bddt, $J=1.0,6.9,8.7 \mathrm{~Hz}, 1 \mathrm{H}), 8.55$ (bd, $J=6.8 \mathrm{~Hz}, 1 \mathrm{H}), 8.87$ (d, $J=$ $6.7 \mathrm{~Hz}, 1 \mathrm{H}), 9.09$ (d, $J=6.8 \mathrm{~Hz}, 1 \mathrm{H}) .{ }^{13} \mathrm{C} \mathrm{NMR}\left(\left(\mathrm{CD}_{3}\right)_{2} \mathrm{CO}\right): \delta 16.9,17.0,26.3,26.7,40.5$, $54.3,56.4,106.5,117.3,120.6,120.6,123.5,125.1,125.3,126.8,126.9,127.6,127.6,128.1$, $128.9,129.0,129.2,130.8,131.4,132.6,136.2$, 137.6, 137.9, 138.6, 139.8, 141.0, 142.27, 142.27, 142.9, 145.3, 147.2, 151.0, 151.8, 154.3. Elemental analysis: (\%) calcd. for $\left[\mathrm{C}_{42} \mathrm{H}_{37} \mathrm{~F}_{6} \mathrm{~N}_{3} \mathrm{O}_{6} \mathrm{~S}_{2}\right] \mathrm{C} 58.80, \mathrm{H} 4.35, \mathrm{~N}$ 4.90; found $\mathrm{C} 58.80, \mathrm{H} 4.18, \mathrm{~N} 4.70$. IR $(\mathrm{KBr}): \tilde{v}\left(\mathrm{~cm}^{-}\right.$ 1) $2805,1630,1605,1590,1552,1506,1495,1445,1427,1412,1383,1358,1278,1262$, $1225,1168,1031,955,888,817,756,672,638,574,518$. MS (ESI): $m / z(\%) 708.3$ [(M $\left.\left.\mathrm{TfO}^{-}\right)^{+}\right](40), 559.3\left[\left(\mathrm{M}-2 \mathrm{TfO}^{-}\right)^{+}\right](15), 279.6\left[\left(\mathrm{M}-2 \mathrm{TfO}^{-}\right)^{2+}\right](61)$. HRMS (ESI): $m / z(\%)$ calcd for $\left[\left(\mathrm{M}-\mathrm{TfO}^{-}\right)^{+}\right]\left(\mathrm{C}_{41} \mathrm{H}_{37} \mathrm{~F}_{3} \mathrm{~N}_{3} \mathrm{O}_{3} \mathrm{~S}\right) 708.25022$; found 708.25122.

Synthesis of 13-((1E,3E)-4-(4-(Dimethylamino)phenyl)buta-1,3-dien-1-yl)-6,7dimethyl-4,5,8,9-tetrahydroisoquinolino[1,2-a]pyrido[1,2-k][2,9]phenanthroline-3,10-

diium Trifluoromethanesulfonate $\left([13]\left[\mathbf{T f O}_{2}\right)\right.$. This compound was prepared and purified in a manner similar to $[\mathbf{1 1}][\mathrm{TfO}]_{2}$ by using $[\mathbf{I I}][\mathrm{TfO}]_{2}(242 \mathrm{mg}, 0.358 \mathrm{mmol})$, 6dimethylamino-2-naphthaldehyde (188 mg, $1.08 \mathrm{mmol}, 3.0$ equiv), dry $\mathrm{MeOH}(4.2 \mathrm{~mL})$ and pyrrolidine ( $350 \mu \mathrm{L}, 303 \mathrm{mg}, 4.26 \mathrm{mmol}, 11.9$ equiv). The reaction time was $20 \mathrm{~min}$. The addition of $\mathrm{Et}_{2} \mathrm{O}(15 \mathrm{~mL})$ was followed by three reprecipitations from $\mathrm{MeOH}(5.0 \mathrm{~mL})$ and a 1.3:1 mixture of EtOAc/ $\mathrm{Et}_{2} \mathrm{O}(70 \mathrm{~mL})$ to give a dark red solid. Yield: $50 \mathrm{mg}(8 \%) .{ }^{1} \mathrm{H}$ NMR $\left(\left(\mathrm{CD}_{3}\right)_{2} \mathrm{CO}\right): \delta 2.52(\mathrm{~s}, 3 \mathrm{H}), 2.52(\mathrm{~s}, 3 \mathrm{H}), 2.99(\mathrm{~s}, 6 \mathrm{H}), 3.10-3.18(\mathrm{~m}, 1 \mathrm{H}), 3.23$ (bdt, $J=4.3$, 16.0, 16.0 Hz, 1H), 3.56-3.62 (m, 2H), $4.92(\mathrm{dt}, J=3.7,14.3,14.3 \mathrm{~Hz}, 1 \mathrm{H}), 4.94-5.00(\mathrm{~m}$, 2H), $5.20(\mathrm{ddd}, J=1.8,4.3,14.2 \mathrm{~Hz}, 1 \mathrm{H}), 6.05(\mathrm{~d}, J=15.3 \mathrm{~Hz}, 1 \mathrm{H}), 6.70-6.73(\mathrm{~m}, 2 \mathrm{H}), 6.72$ $(\mathrm{dd}, J=10.5,15.3 \mathrm{~Hz}, 1 \mathrm{H}), 6.80(\mathrm{~d}, J=15.3 \mathrm{~Hz}, 1 \mathrm{H}), 6.92(\mathrm{dd}, J=10.5,15.3 \mathrm{~Hz}, 1 \mathrm{H}), 7.07$ $(\mathrm{d}, J=2.0 \mathrm{~Hz}, 1 \mathrm{H}), 7.42-7.45(\mathrm{~m}, 2 \mathrm{H}), 7.62(\mathrm{ddd}, J=1.2,6.9,8.7 \mathrm{~Hz}, 1 \mathrm{H}), 7.63(\mathrm{dd}, J=2.0$, $6.7 \mathrm{~Hz}, 1 \mathrm{H}), 7.89$ (dq, $J=0.9,8.7 \mathrm{~Hz}, 1 \mathrm{H}), 7.92(\mathrm{ddd}, J=1.2,6.9,8.7 \mathrm{~Hz}, 1 \mathrm{H}), 8.16$ (bd, $J=$ $8.2 \mathrm{~Hz}, 1 \mathrm{H}), 8.55(\mathrm{bd}, J=6.7 \mathrm{~Hz}, 1 \mathrm{H}), 8.77(\mathrm{~d}, J=6.7 \mathrm{~Hz}, 1 \mathrm{H}), 9.07(\mathrm{~d}, J=6.7 \mathrm{~Hz}, 1 \mathrm{H}) .{ }^{13} \mathrm{C}$ NMR $\left(\left(\mathrm{CD}_{3}\right)_{2} \mathrm{CO}\right): \delta 16.4,16.5,25.0,25.2,39.6,52.4,54.5,111.9,119.8,122.0,122.2$, $122.5,123.3,123.9,124.4,125.3,126.8,127.6,127.8,129.2,131.2,135.0,136.5,137.4$, 
$138.1,139.2,140.6,140.8,142.2,143.0,144.0,145.2,150.1,151.2$, 152.0. Elemental analysis: (\%). calcd. for $\left[\mathrm{C}_{40} \mathrm{H}_{37} \mathrm{~N}_{3} \mathrm{O}_{6} \mathrm{~S}_{2}\right] \mathrm{C}$ 57.62, $\mathrm{H}$ 4.47, $\mathrm{N}$ 5.04; found $\mathrm{C}$ 57.66, H 4.62, 5.00. IR (KBr): $\tilde{v}\left(\mathrm{~cm}^{-1}\right)$ 2804, 1631, 1611, 1567, 1524, 1507, 1444, 1434, 1410, 1393, 1275 , 1256, 1188, 1149, 1109, 1029, 945, 887, 814, 755, 680, 637, 573. MS (ESI): $m / z(\%) 684.3$ $\left[\left(\mathrm{M}-\mathrm{TfO}^{-}\right)^{+}\right](100), 535.3\left[\left(\mathrm{M}-2 \mathrm{TfO}^{-}\right)^{+}\right](33), 267.6\left[\left(\mathrm{M}-2 \mathrm{TfO}^{-}\right)^{2+}\right](65)$. HRMS (ESI): $m / z(\%)$ calcd for $\left[\left(\mathrm{M}-\mathrm{TfO}^{-}\right)^{+}\right]\left(\mathrm{C}_{39} \mathrm{H}_{37} \mathrm{O}_{3} \mathrm{~N}_{3} \mathrm{~F}_{3} \mathrm{~S}\right) 684.25022$; found 684.25034.

Synthesis of 13-((1E,3E)-4-(1,2,3,5,6,7-Hexahydropyrido[3,2,1-ij]quinolin-9yl)buta-1,3-dienyl)-6,7-dimethyl-4,5,8,9-tetrahydroisoquinolino[1,2-a]pyrido[1,2$k][2,9]$ phenanthroline-3,10-diium Trifluoromethanesulfonate $\quad\left([14]\left[\mathrm{TfO}_{2}\right) . \quad\right.$ This compound was prepared and purified in a manner similar to $[\mathbf{1 1}][\mathrm{TfO}]_{2}$ by using $[\mathbf{I I}][\mathrm{TfO}]_{2}$ (74 mg, $0.109 \mathrm{mmol}),(E)-3-(j u l o l i d i n y l) a c r y l a l d e h y d e^{9}$ (74 mg, $0.326 \mathrm{mmol}, 3.0$ equiv), dry $\mathrm{MeOH}(6.0 \mathrm{~mL})$ and pyrrolidine $(109 \mu \mathrm{L}, 94 \mathrm{mg}, 1.33 \mathrm{mmol}, 12.2$ equiv). The reaction time was $70 \mathrm{~min}$. The addition of $\mathrm{Et}_{2} \mathrm{O}(60 \mathrm{~mL})$ was followed by three reprecipitations from $\mathrm{MeOH}(1.0 \mathrm{~mL})$ and $\mathrm{Et}_{2} \mathrm{O}(20 \mathrm{~mL})$ to give a dark blue solid. Yield: $44 \mathrm{mg}(45 \%) .{ }^{1} \mathrm{H}$ NMR $\left(\left(\mathrm{CD}_{3}\right)_{2} \mathrm{CO}\right): \delta 1.92-1.97(\mathrm{~m}, 4 \mathrm{H}), 2.51$ (s, 3H), 2.58 (s, 3H), 2.71-2.74 (m, 4H), 3.27 (bdt, $J$ $=4.8,15.8 \mathrm{~Hz}, 1 \mathrm{H}), 3.28-3.31(\mathrm{~m}, 4 \mathrm{H}), 3.38(\mathrm{bdt}, J=4.9,15.5 \mathrm{~Hz}, 1 \mathrm{H}), 3.64(\mathrm{ddd}, J=1.8$, 3.8, 16.8 Hz, 1H), 3.69 (ddd, $J=1.9,3.7,16.9 \mathrm{~Hz}, 1 \mathrm{H}), 5.04(\mathrm{dt}, J=3.8,14.3 \mathrm{~Hz}, 1 \mathrm{H}), 5.14$ (ddd, $J=1.8,4.8,13.8 \mathrm{~Hz}, 1 \mathrm{H}), 5.31$ (ddd, $J=1.9,4.9,13.8 \mathrm{~Hz}, 1 \mathrm{H}), 5.37$ (dt, $J=3.7,14.2$ $\mathrm{Hz}, 1 \mathrm{H}), 6.03(\mathrm{~d}, J=15.1 \mathrm{~Hz}, 1 \mathrm{H}), 6.51(\mathrm{dd}, J=10.9,10.9 \mathrm{~Hz}, 1 \mathrm{H}), 6.78(\mathrm{~d}, J=15.1 \mathrm{~Hz}$, 1H), $6.95(\mathrm{~s}, 1 \mathrm{H}), 7.10$ (bdd, $J=10.9,15.1 \mathrm{~Hz}, 1 \mathrm{H}), 7.26(\mathrm{~d}, J=1.9 \mathrm{~Hz}, 1 \mathrm{H}), 7.51(\mathrm{dd}, J=$ 1.9, $6.6 \mathrm{~Hz}, 1 \mathrm{H}), 7.73$ (ddd, $J=1.3,6.9,8.7 \mathrm{~Hz}, 1 \mathrm{H}), 7.92$ (ddd, $J=1.1,6.9,8.2 \mathrm{~Hz}, 1 \mathrm{H})$, $8.03(\mathrm{dq}, J=0.9,8.7 \mathrm{~Hz}, 1 \mathrm{H}), 8.18$ (bddt, $J=0.7,1.3,8.2 \mathrm{~Hz}, 1 \mathrm{H}), 8.51$ (bd, $J=6.7 \mathrm{~Hz}, 1 \mathrm{H})$, $8.68(\mathrm{~d}, J=6.6 \mathrm{~Hz}, 1 \mathrm{H}), 9.07(\mathrm{~d}, J=6.7 \mathrm{~Hz}, 1 \mathrm{H}) .{ }^{13} \mathrm{C} \mathrm{NMR}\left(\left(\mathrm{CD}_{3}\right)_{2} \mathrm{CO}\right): \delta 16.9,16.9,22.3$, $26.4,26.6,28.3,50.5,53.9,56.3,120.3,121.2,122.0,122.5,123.9,125.7,123.5,125.0$, $126.8,128.0,128.3,128.8,128.9,132.4,136.0,137.9,138.7,139.6,140.7,142.0,142.1$, 144.8, 144.8, 145.1, 145.5, 146.4, 151.9, 154.0. Elemental analysis: (\%). calcd. for $\left[\mathrm{C}_{44} \mathrm{H}_{41} \mathrm{~F}_{6} \mathrm{~N}_{3} \mathrm{O}_{6} \mathrm{~S}_{2}\right] \mathrm{C} 59.65, \mathrm{H} 4.66, \mathrm{~N} 4.74$; found $\mathrm{C} 59.52, \mathrm{H} 4.87, \mathrm{~N} 4.51$. IR $(\mathrm{KBr}): \tilde{v}\left(\mathrm{~cm}^{-}\right.$ 1) $3079,1632,1609,1560,1506,1466,1270,1223,1145,1030,867,792,754,637,572$. MS (ESI): $m / z(\%) 736.3\left[\left(\mathrm{M}-\mathrm{TfO}^{-}\right)^{+}\right](1), 586.3\left[\left(\mathrm{M}-2 \mathrm{TfO}^{-}-\mathrm{H}\right)^{+}\right](1), 293.7\left[\left(\mathrm{M}-2 \mathrm{TfO}^{-}\right)^{2+}\right]$ 
(100). HRMS (ESI): $m / z$ (\%) calcd for $\left[\left(\mathrm{M}-\mathrm{TfO}^{-}\right)^{+}\right]\left(\mathrm{C}_{43} \mathrm{H}_{41} \mathrm{O}_{3} \mathrm{~N}_{3} \mathrm{~F}_{3} \mathrm{~S}\right)$ 736.28152; found 736.28168.

X-Ray Crystallography. Data for the compounds $[2]\left[\mathrm{PF}_{6}\right]_{2} \cdot \mathrm{MeCN}$ and $[6][\mathrm{TfO}]_{2}$ were collected on a Nonius KappaCCD diffractometer equipped with a Bruker APEX-II CCD detector by using monochromatized MoK $\alpha$ radiation $(\lambda=0.71073 \AA)$ at a temperature of $150(2) \mathrm{K}$. The structures were solved by direct methods by using SHELXS-97, ${ }^{47}$ and refined by full-matrix least-squares on all $F_{0}{ }^{2}$ data by using SHELXL-2014. ${ }^{48}$ All non-hydrogen atoms were refined anisotropically and hydrogen atoms were fixed into idealized positions (riding model) and assigned temperature factors $H_{\text {iso }}(\mathrm{H})=1.2 U_{\text {eq }}($ pivot atom) or 1.5 for methyl moieties. In $[2]\left[\mathrm{PF}_{6}\right]_{2} \cdot \mathrm{MeCN}$, the $\mathrm{PF}_{6}{ }^{-}$anions and the solvent molecule are disordered over several positions. This disorder was described by using unconstrained large displacement parameters to lower the R-factors. Crystallographic data and refinement details are included in the Supporting Information (Table S1).

Hyper-Rayleigh Scattering. General details of the HRS experiment have been discussed elsewhere, ${ }^{49,50}$ and the apparatus and experimental procedures used for the fs studies were exactly as described previously. ${ }^{35}$ These measurements were carried out in $\mathrm{MeCN}$, and the reference compound was crystal violet (octupolar $\beta_{y y y, 800}=500 \times 10^{-30}$ esu in $\mathrm{MeCN}$; from the value of $340 \times 10^{-30}$ esu in $\mathrm{MeOH}$, corrected for local field factors at optical frequencies). For all measurements, dilute solutions $\left(1-5 \times 10^{-5} \mathrm{M}\right)$ were used to ensure a linear dependence of $I_{2} / I_{\omega}^{2}$ on concentration, precluding the need for Lambert-Beer correction factors. The absence of demodulation at $800 \mathrm{~nm}$, i.e. constant values of $\beta$ versus frequency, confirmed that no fluorescence contributions to the HRS signals were present at $400 \mathrm{~nm}$ for most of the compounds. Some fluorescence was detected for the salts $[6][\mathrm{TfO}]_{2}$ and $[\mathbf{1 1}][\mathrm{TfO}]_{2}$, but this has been accounted for by the data processing protocol used. The reported $\beta$ values are the averages taken from measurements at different amplitude modulation frequencies $(80,160,240 \mathrm{MHz}$, and also $320 \mathrm{MHz}$ in some cases).

Stark Spectroscopy. The Stark apparatus, experimental methods and data collection procedure were as previously reported, ${ }^{51,52}$ except that a Xe arc lamp was used as the light source instead of a W filament bulb. The Stark spectrum for each compound was measured at 
least twice. Satisfactory fits of the Stark data for the salts $[\mathbf{1}-\mathbf{3}][\mathrm{TfO}]_{2}$ and $[\mathbf{1 0}-\mathbf{1 4}][\mathrm{TfO}]_{2}$ were obtained by using the observed absorption ( $(\varepsilon / v$ vs $v)$ spectra, but for $[4-9][\mathrm{TfO}]_{2}$ these spectra were modeled with a sum of three Gaussian curves that reproduce the data and separate the peaks. The data analysis was carried out as previously described, ${ }^{51,52}$ by using the zeroth, first and second derivatives of the absorption spectrum (or the first and second derivatives of the Gaussian curves) for analysis of the Stark $\Delta \varepsilon(v)$ spectrum in terms of the Liptay treatment. ${ }^{40}$ The dipole-moment change, $\Delta \mu_{12}=\mu_{\mathrm{e}}-\mu_{\mathrm{g}}$, where $\mu_{\mathrm{e}}$ and $\mu_{\mathrm{g}}$ are the respective excited and ground-state dipole moments, was then calculated from the coefficient of the second derivative component. PrCN was used as the glassing medium, for which the local field correction $f_{\text {int }}$ is estimated as 1.33. The value of the transition dipole-moment $\mu_{12}$ can be determined from the oscillator strength $f_{\text {os }}$ of the transition by eq 1 .

$$
\left|\mu_{12}\right|=\left(\frac{f_{\mathrm{os}}}{1.08 \times 10^{-5} E_{\max }}\right)^{1 / 2}
$$

where $E_{\max }$ is the energy of the ICT maximum (in wavenumbers) and $\mu_{12}$ is in eA. The latter is converted into Debye units on multiplying by 4.803 . If the hyperpolarizability $\beta_{0}$ tensor has only nonzero elements along the ICT direction, then this quantity is given by eq 2 .

$$
\beta_{0}=\frac{3 \Delta \mu_{12}\left(\mu_{12}\right)^{2}}{\left(E_{\max }\right)^{2}}
$$

A relative error of $\pm 20 \%$ is estimated for the $\beta_{0}$ values derived from the Stark data and using eq 2, while experimental errors of $\pm 10 \%$ are estimated for $\mu_{12}$ and $\Delta \mu_{12}$. Note that the $\pm 20 \%$ uncertainty for the $\beta_{0}$ values is merely statistical and does not account for any errors introduced by two-state extrapolation.

Theoretical Studies. DFT calculations were performed by using the Gaussian 09 program package. ${ }^{42}$ The ground-state structures of the Hqs were optimized in the gas phase. The first 50 excited singlet states were calculated via TD-DFT, using a conductor-like polarizable continuum model $(\mathrm{CPCM})^{53,54}$ to account for the $\mathrm{MeCN}$ solvent. The MOs were 
generated by using the GaussView program, ${ }^{55}$ and UV-vis spectra were simulated by using the GaussSum program. ${ }^{56}$ In each case, the curve fwhm was adjusted slightly (by no more than $500 \mathrm{~cm}^{-1}$ ) from the default value of $3000 \mathrm{~cm}^{-1}$ in order to give the best fit with the measured spectrum.

$\beta_{0}$ values were calculated both in the gas phase and in $\mathrm{MeCN}$ by using CAMB3LYP/6-311G(d), as the analytical second derivatives of the dipole moment with respect to an external electric field. The calculated $\beta_{\text {tot }}$ value is the overall magnitude of the static first hyperpolarizability related to the individual tensor components according to eq 3 and eq $4 . .^{57}$

$$
\beta_{\text {tot }}=\left[\left(\beta_{x x x}+\beta_{x y y}+\beta_{x z z}\right)^{2}+\left(\beta_{y y y}+\beta_{y z z}+\beta_{y x x}\right)^{2}+\left(\beta_{z z z}+\beta_{z x x}+\beta_{z y y}\right)^{2}\right]^{\frac{1}{2}}
$$

and

$$
\beta_{\mathrm{tot}}=\left(\beta_{x}^{2}+\beta_{y}^{2}+\beta_{z}^{2}\right)^{\frac{1}{2}}
$$

For the molecules studied here with $C_{1}$ point group symmetry, Gaussian 09 assigns the $x$ axis as approximately coincident with the dipolar axis, i.e. the electron donor group to $\mathrm{Hq}$ vector.

\section{ASSOCIATED CONTENT}

\section{Supporting Information}

The Supporting Information is available free of charge on the ACS Publications website at DOI: 10.1021/acs.jpca????????

${ }^{1} \mathrm{H}$ and ${ }^{13} \mathrm{C}$ NMR spectra of all new compounds, crystallographic and theoretical data (PDF) CIF file (CCDC 1532597 and 1532598). 


\section{AUTHOR INFORMATION}

\section{Corresponding Authors}

*E-mail: b.coe@manchester.ac.uk (B. J. Coe)

*E-mail: filip.teply@uochb.cas.cz (F. Teplý)

ORCID

Benjamin J. Coe: 0000-0002-5998-3895

F. Teplý: 0000-0003-3459-556X

Notes

The authors declare no competing financial interest.

\section{ACKNOWLEDGMENTS}

This work was supported by ASCR (RVO: 61388963, M200551208 to F.T.), the Czech Science Foundation (13-19213S to F.T.), Ministry of Health of the Czech Republic (1631156A to F.T.), the Fund for Scientific Research-Flanders (Research Grant 1510712N), the University of Leuven (GOA/2011/03), and the EPSRC (grants EP/G020299/1 and EP/J018635/1 to B.J.C.). B.S.B. acknowledges the Beckman Institute of the California Institute of Technology for support.

\section{REFERENCES}

(1) Bamfield, P.; Hutchings, M. G., Chromic Phenomena: Technological Applications of Colour Chemistry, 2nd Edition, The Royal Society of Chemistry, Cambridge, 2010.

(2) Bureš, F. Fundamental Aspects of Property Tuning in Push-Pull Molecules. RSC $A d v .2014,4,58826-58851$.

(3) Xu, H.; Chen, R.-F.; Sun, Q.; Lai, W.-Y.; Su, Q.-Q.; Huang, W.; Liu, X.-G. Recent Progress in Metal-Organic Complexes for Optoelectronic Applications. Chem. Soc. Rev. 2014, 43, 3259-3302.

(4) Metzger, R. M. Unimolecular Electronics. Chem. Rev. 2015, 115, 5056-5115. 
(5) Nonlinear Optics of Organic Molecules and Polymers; Nalwa, H. S., Miyata, S., Eds.; CRC Press: Boca Raton, FL, 1997.

(6) Nonlinear Optical Properties of Matter: From Molecules to Condensed Phases; Papadopoulos, M. G.; Leszczynski, J.; Sadlej, A. J., Eds.; Springer: Dordrecht, 2006.

(7) De Meulenaere, E.; Chen, W.-Q.; Van Cleuvenbergen, S.; Zheng, M.-L.; Psilodimitrakopoulos, S.; Paesen, R.; Taymans, J.-M.; Ameloot, M.; Vanderleyden, J.; LozaAlvarez, P.; et al. Molecular Engineering of Chromophores for Combined Second-Harmonic and Two-Photon Fluorescence in Cellular Imaging. Chem. Sci. 2012, 3, 984-995 and refs therein.

(8) Dalton, L. R.; Günter, P; Jazbinsek, M.; Kwon, O.-P.; Sullivan, P. A. Organic Electro-Optics and Photonics: Molecules, Polymers and Crystals; Cambridge University Press, Cambridge U.K., 2015.

(9) Taniuchi, T.; Okada, S.; Nakanishi, H. Widely Tunable Terahertz-Wave Generation in an Organic Crystal and its Spectroscopic Application. J. Appl. Phys. 2004, 95, $5984-5988$.

(10) Schneider, A.; Neis, M.; Stillhart, M.; Ruiz, B.; Khan, R. U. A.; Günter, P. Generation of Terahertz Pulses Through Optical Rectification in Organic DAST Crystals: Theory and Experiment. J. Opt. Soc. Am. B 2006, 23, 1822-1835.

(11) Macchi, R.; Cariati, E.; Marinotto, D.; Roberto, D.; Tordin, E.; Ugo, R.; Bozio, R.; Cozzuol, M.; Pedron, D.; Mattei, G. Stable SHG from in situ Grown Oriented Nanocrystals of $[(\mathrm{E})-N, N$-dimethylamino- $N$-methylstilbazolium][p-toluenesulfonate $]$ in a PMMA Film. J. Mater. Chem. 2010, 20, 1885-1890.

(12) Zheng, M.-L.; Fujita, K.; Chen, W.-Q.; Duan, X.-M.; Kawata, S. Two-Photon Excited Fluorescence and Second-Harmonic Generation of the DAST Organic Nanocrystals. J. Phys. Chem. C 2011, 115, 8988-8993.

(13) Marinotto, D.; Lucenti, E.; Scavia, G.; Ugo, R.; Tavazzi, S.; Mattei, G. Cariati, E. Spontaneous in situ Thermal Growth of Oriented Acentric Nanocrystals of $[(E)-N, N-$ dimethylamino- $N^{\prime}$-methylstilbazolium $][p$-toluenesulfonate $]$ Embedded in a PMMA Film on ITO Generating Stable SHG. J. Mater. Chem. C 2014, 2, 8532-8538. 
(14) http://www.rainbowphotonics.com, accessed 12/07/2017.

(15) Terahertz Sources and Systems; Miles, R. E., Harrison, P., Lippens, D., Eds.; NATO Science Series II, Vol. 27; Kluwer: Dordrecht, 2001.

(16) Ferguson, B.; Zhang, X.-C. Materials for Terahertz Science and Technology. Nat. Mater. 2002, 1, 26-33.

(17) McEntee, J. The Terhartz Gap: into the Dead Zone. Chemistry World, March 2007, pp. 52-56.

(18) Jeong, J.-H.; Kang, B.-J.; Kim, J.-S.; Jazbinsek, M.; Lee, S.-H.; Lee, S.-C.; Baek, I.-H.; Yun, H.; Kim, J.; Lee, Y. S.; et al. High-Power Broadband Organic THz Generator. Sci. Rep. 2013, 3, 3200.

(19) http://www.teraview.com, accessed 12/07/2017.

(20) Coe, B. J.; Harris, J. A.; Brunschwig, B. S.; Garín, J.; Orduna, J. Molecular Salts with Diquat-Based Electron Acceptors for Nonlinear Optics. J. Am. Chem. Soc. 2005, 127, $3284-3285$.

(21) Coe, B. J.; Fielden, J.; Foxon, S. P.; Harris, J. A.; Helliwell, M.; Brunschwig, B. S.; Asselberghs, I.; Clays, K.; Garín, J.; Orduna, J. Diquat Derivatives: Highly Active, TwoDimensional Nonlinear Optical Chromophores with Potential Redox Switchability. J. Am. Chem. Soc. 2010, 132, 10498-10512.

(22) Coe, B. J.; Fielden, J.; Foxon, S. P.; Helliwell, M.; Brunschwig, B. S.; Asselberghs, I; Clays, K; Olesiak, J.; Matczyszyn, K.; Samoc, M. Quadratic and Cubic Nonlinear Optical Properties of Salts of Diquat-Based Chromophores with Diphenylamino Substituents. J. Phys. Chem. A 2010, 114, 12028-12041.

(23) Coe, B. J.; Fielden, J.; Foxon, S. P.; Asselberghs, I.; Clays, K.; Van Cleuvenbergen, S.; Brunschwig, B. S. Ferrocenyl Diquat Derivatives: Nonlinear Optical Activity, Multiple Redox States, and Unusual Reactivity. Organometallics 2011, 30, 57315743.

(24) Verbiest, T.; Persoons, A. in Materials Chirality: Topics in Stereochemistry; Green, M. M.; Nolte, R. J. M.; Meijer, E. W.; Denmark, S. E.; Siegel, J., Eds.; Wiley: New York, 2003; Vol. 24, pp. 519-570. 
(25) Ziolo, R. F.; Günther, W. H. H.; Meredith, G. R.; Williams, D. J.; Troup, J. M. The Structure of trans-4'-Hydroxy- $N$-Methyl-4-Stilbazolium (+)-Camphor-10-Sulfonate. Acta Crystallogr., Sect. B 1982, 38, 341-343.

(26) Andreu, R.; Malfant, I.; Lacroix, P. G.; Gornitzka, H.; Nakatani, K. Chiral Stilbazolium Chromophores: An Approach toward Multiproperty Materials Combining Conductivity and Second-Order Optical Nonlinearities. Chem. Mater. 1999, 11, 840-848.

(27) Yan, P.; Millard, A. C.; Wei, M.; Loew, L. M. Unique Contrast Patterns from Resonance-Enhanced Chiral SHG of Cell Membranes. J. Am. Chem. Soc. 2006, 128, 11030 11031.

(28) Reyes-Gutiérrez, P. E.; Jirásek, M.; Severa, L.; Novotná, P.; Koval, D.; Sázelová, P.; Vávra, J.; Meyer, A.; Císařová, I.; Šaman, D.; et al. Functional Helquats: Helical Cationic Dyes with Marked, Switchable Chiroptical Properties in the Visible Region. Chem. Commun. 2015, 51, 1583-1586.

(29) Coe, B. J.; Rusanova, D.; Joshi, V. D.; Sánchez, S.; Vávra, J.; Khobragade, D.; Severa, L.; Císařová, I.; Šaman, D.; Pohl, R.; et al. Helquat Dyes: Helicene-like Push-Pull Systems with Large Second-Order Nonlinear Optical Responses. J. Org. Chem. 2016, 81, 1912-1920.

(30) Buckley, L. E. R.; Coe, B. J.; Rusanova, D.; Sánchez, S.; Jirásek, M.; Joshi, V. D.; Vávra, J.; Khobragade, D.; Pospíšil, L.; Ramešová, S.; et al. Ferrocenyl Helquats: Unusual Chiral Organometallic Nonlinear Optical Chromophores. Dalton Trans. 2017, 46, 1052-1064.

(31) Teplý, F.; Hájek, M. Helquat Derivatives, Preparation thereof, and use thereof as Medicaments. WO2014111069 A1.

(32) Severa, L.; Koval, D.; Novotná, P.; Ončák, M.; Sázelová, P.; Šaman, D.; Slavíček, P.; Urbanová, M.; Kašička, V.; Teplý, F. Resolution of a Configurationally Stable [5]helquat: Enantiocomposition Analysis of a Helicene Congener by Capillary Electrophoresis. New J. Chem. 2010, 34, 1063-1067. 
(33) Resolution of II: Šebestík, J.; Teplý, F.; Císařová, I.; Vávra, J.; Koval, D.; Bouř, P. Intense Chirality Induction in Nitrile Solvents by a Helquat Dye Monitored by Near Resonance Raman Scattering. Chem. Commun. 2016, 52, 6257-6260.

(34) Coe, B. J.; Harris, J. A.; Asselberghs, I.; Wostyn, K.; Clays, K.; Persoons, A.; Brunschwig, B. S.; Coles, S. J.; Gelbrich, T.; Light, M. E., et al. Quadratic Optical Nonlinearities of $N$-Methyl and $N$-Aryl Pyridinium Salts. Adv. Funct. Mater. 2003, 13, 347357.

(35) Olbrechts, G.; Clays, K.; Persoons, A. J. Opt. Soc. Am. B 2000, 17, 1867-1873.

(36) Oudar, J. L.; Chemla, D. S. Hyperpolarizabilities of the Nitroanilines and their Relations to the Excited State Dipole Moment. J. Chem. Phys. 1977, 66, 2664-2668.

(37) Oudar, J. L. Optical Nonlinearities of Conjugated Molecules. Stilbene Derivatives and Highly Polar Aromatic Compounds. J. Chem. Phys. 1977, 67, 446-457.

(38) Clays, K.; Coe, B. J. Design Strategies Versus Limiting Theory for Engineering Large Second-Order Nonlinear Optical Polarizabilities in Charged Organic Molecules. Chem. Mater. 2003, 15, 642-648.

(39) Coe, B. J.; Foxon, S. P.; Harper, E. C.; Harris, J. A.; Helliwell, M.; Raftery, J.; Asselberghs, I.; Clays, K.; Franz, E.; Brunschwig, B. S.; et al. The Syntheses, Structures and Nonlinear Optical and Related Properties of Salts with Julolidinyl Electron Donor Groups. Dyes Pigments 2009, 82, 171-186.

(40) Liptay, W. Dipole Moments and Polarizabilities of Molecules in Excited Electronic States. In Excited States, Vol. 1; Lim, E. C., Ed.; Academic Press, New York, 1974, pp. 129-229.

(41) Bublitz, G. U.; Boxer, S. G. Stark Spectroscopy: Applications in Chemistry, Biology, and Materials Science. Annu. Rev. Phys. Chem. 1997, 48, 213-242.

(42) Gaussian 09, Revision E.01, Frisch, M. J.; Trucks, G. W.; Schlegel, H. B.; Scuseria, G. E.; Robb, M. A.; Cheeseman, J. R.; Scalmani, G.; Barone, V.; Mennucci, B.; Petersson, G. A.; et al. Gaussian, Inc., Wallingford CT, 2009.

(43) Becke, A. D. Density-Functional Thermochemistry. III. The Role of Exact Exchange. J. Chem. Phys. 1993, 98, 5648-5652. 
(44) Zhao, Y.; Truhlar, D. The M06 Suite of Density Functionals for Main Group Thermochemistry, Thermochemical Kinetics, Noncovalent Interactions, Excited States, and Transition Elements: Two New Functionals and Systematic Testing of Four M06-Class Functionals and 12 other Functionals. Theor. Chem. Acc. 2008, 120, 215-241.

(45) Yanai, T.; Tew, D. P.; Handy, N. C. A New Hybrid Exchange-Correlation Functional using the Coulomb-Attenuating Method (CAM-B3LYP). Chem. Phys. Lett. 2004, 393, 51-57.

(46) Amabilino, D. B.; Ashton, P. R.; Reder, A. S.; Spencer N.; Stoddart, J. F. Olympiadane. Angew. Chem. Int. Ed. Engl. 1994, 33, 1286-1290.

(47) Sheldrick, G. M. Phase Annealing in SHELX-90: Direct Methods for Larger Structures. Acta Crystallogr., Sect. A 1990, 46, 467-473.

(48) Sheldrick, G. M. Crystal Structure Refinement with SHELXL. Acta Crystallogr., Sect. $C, \mathbf{2 0 1 5}, 71,3-8$.

(49) Clays, K.; Persoons, A. Hyper-Rayleigh Scattering in Solution. Rev. Sci. Instrum. 1992, 63, 3285-3289.

(50) Hendrickx, E.; Clays, K.; Persoons, A. Hyper-Rayleigh Scattering in Isotropic Solution. Acc. Chem. Res. 1998, 31, 675-683.

(51) Coe, B. J.; Harris, J. A.; Brunschwig, B. S. Electroabsorption Spectroscopic Studies of Dipolar Ruthenium(II) Complexes Possessing Large Quadratic Nonlinear Optical Responses. J. Phys. Chem. A 2002, 106, 897-905.

(52) Shin, Y. K.; Brunschwig, B. S.; Creutz, C.; Sutin, N. Electroabsorption Spectroscopy of Charge-Transfer States of Transition-Metal Complexes. 2. Metal-to-Ligand and Ligand-to-Metal Charge-Transfer Excited States of Pentaammineruthenium Complexes. J. Phys. Chem. 1996, 100, 8157-8169.

(53) Barone, V.; Cossi, M. Quantum Calculation of Molecular Energies and Energy Gradients in Solution by a Conductor Solvent Model. J. Phys. Chem. A 1998, 102, 19952001. 
(54) Cossi, M.; Rega, N.; Scalmani, G.; Barone, V. Energies, Structures, and Electronic Properties of Molecules in Solution with the C-PCM Solvation Model. J. Comput. Chem. 2003, 24, 669-681.

(55) GaussView, Version 5, Dennington, R.; Keith, T.; Millam, J. Semichem Inc., Shawnee Mission, KS, 2009.

(56) O’Boyle, N. M.; Tenderholt, A. L.; Langner, K. M. Software News and Updates cclib: A Library for Package-Independent Computational Chemistry Algorithms. J. Comput. Chem. 2008, 29, 839-845.

(57) Thanthiriwatte, K. S.; Nalin de Silva, K. M. Non-linear optical properties of novel fluorenyl derivatives-ab initio quantum chemical calculations. J. Mol. Struct. (Theochem) 2002, 617, 169-175. 


\section{TABLE OF CONTENTS GRAPHIC}

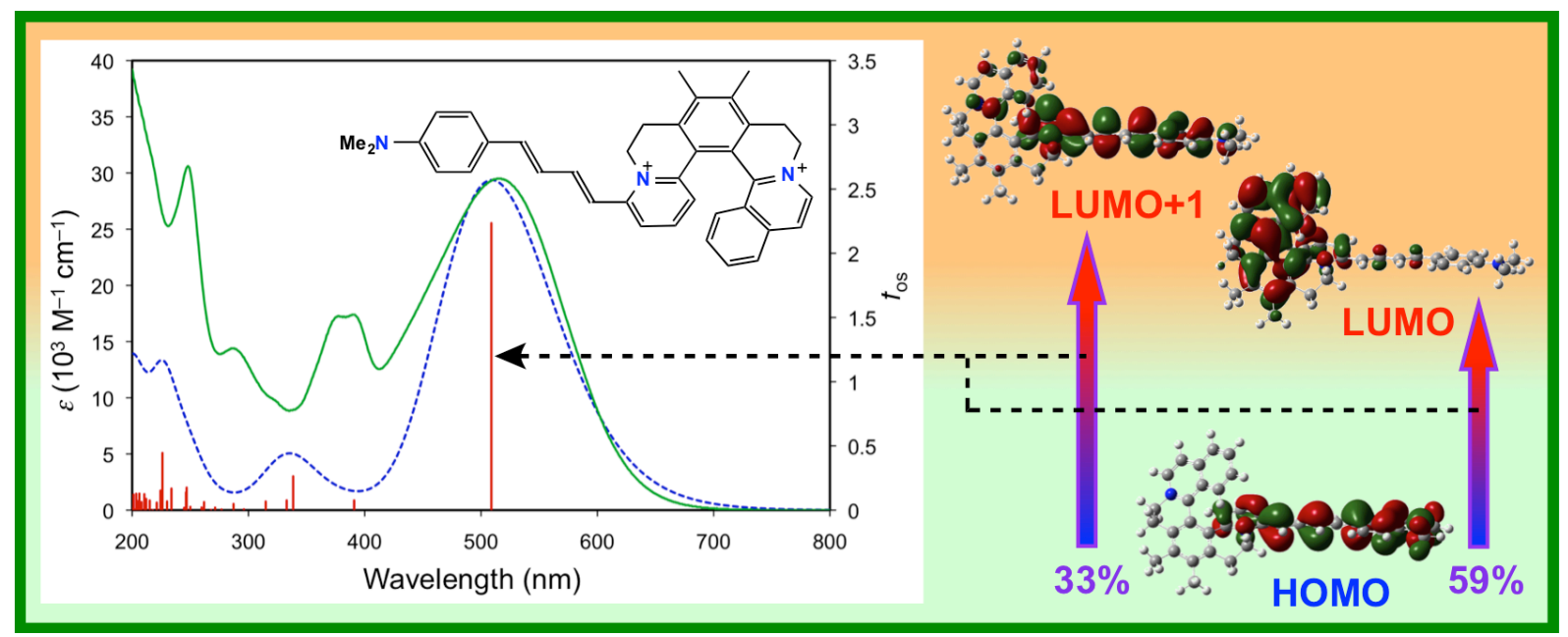

